See discussions, stats, and author profiles for this publication at: https://www.researchgate.net/publication/324686974

\title{
Estrogenic Compounds: Chemical Characteristics, Detection Methods, Biological and Environmental Effects
}

Article in Water Air and Soil Pollution · May 2018

Dol: 10.1007/s11270-018-3796-z

\section{CITATION}

4 authors:

(क्)

Maria Tereza Pamplona-Silva

São Paulo State University

7 PUBLICATIONS 7 CITATIONS

SEE PROFILE

Jaqueline Bianchi

7 PUBLICATIONS 102 CITATIONS

SEE PROFILE
232

Dânia Elisa Christofoletti Mazzeo

São Paulo State University

19 PUBLICATIONS 564 CITATIONS

SEE PROFILE

2. Maria Aparecida Marin-Morales

São Paulo State University

116 PUBLICATIONS 2,808 CITATIONS

SEE PROFILE

Some of the authors of this publication are also working on these related projects:

Project $\quad$ AVALIAÇÃO DOS EFEITOS TÓXICOS E GENÉTICOS DE MICROCISTINAS SOB SISTEMAS TESTES ANIMAIS E VEGETAIS View project

Project $\quad$ AVALIAÇÃO DOS EFEITOS TOXICOGENÉTICOS DE COMPOSTOS QUÍMICOS POLUIDORES DE RECURSOS HÍDRICOS, POR MEIO DE DIFERENTES BIOENSAIOS. VieW PROjeCt 


\title{
Estrogenic Compounds: Chemical Characteristics, Detection Methods, Biological and Environmental Effects
}

\author{
Maria Tereza Pamplona-Silva • \\ Dânia Elisa Christofoletti Mazzeo • \\ Jaqueline Bianchi • Maria Aparecida Marin-Morales
}

Received: 10 April 2017 / Accepted: 12 April 2018

C) Springer International Publishing AG, part of Springer Nature 2018

\begin{abstract}
Several chemical compounds are being studied for their capacities to cause imbalances in several biological systems. Some of those are able to affect the endocrine system and are known as endocrine disruptors. Many negative effects can be induced in the organisms by the action of these chemicals, highlighting the capacity to cause a decrease in the fertility rate, sex inversion, and problems in embryonic development and even cancer in humans. Those contaminants can be found in different environmental conditions, in groundwater, sediments, residual waters, sludges, and even in drinking water. The purpose of this review is to provide a general overview of the main estrogenic endocrine disruptors and their effects on living organisms, showing the most frequently used tools to detect these contaminants in environmental matrices. According to the data found, there is a need to develop more studies and improve the techniques, in order to effectively determine the mechanism of action of these contaminants and, thus, establish appropriate strategies for their removal from the environment and reduce their actions on living beings.
\end{abstract}

M. T. Pamplona-Silva • D. E. C. Mazzeo • J. Bianchi ·

M. A. Marin-Morales $(\bowtie)$

Department of Biology, Institute of Biosciences, UNESP - Univ

Estadual Paulista, Av. 24-A, 1515, 13, Rio Claro, SP 506-900,

Brazil

e-mail:mamm@rc.unesp.br

D. E. C. Mazzeo

Department of Analytical Chemistry, Institute of Chemistry,

UNESP - Univ Estadual Paulista, Araraquara, SP, Brazil
Keywords Endocrine disruptors · Environmental estrogenicity · Estrogen receptor Estrogenic hormones . Bioassay $\cdot$ Epigenetic

$\begin{array}{ll}\text { Abbreviations } \\ \text { 17 } \alpha \text { EE2 } & \text { 17 } \alpha \text {-Ethinylestradiol } \\ \text { 17ßE2 } & \text { 17ß-Estradiol } \\ \text { 4-CP } & \text { 4-Cumylphenol } \\ \text { APEO } & \text { Alkylphenol ethoxylates } \\ \text { APS } & \text { Alkylphenols } \\ \text { BBzP } & \text { Butylbenzyl phthalate } \\ \text { BCFs } & \text { Bioconcentration Factors } \\ \text { BPA } & \text { Bisphenol A } \\ \text { DEHP } & \text { Di(2-ethylhexyl) phthalate } \\ \text { DEP } & \text { Diethyl phthalate } \\ \text { DES } & \text { Diethylstilbestrol } \\ \text { DiBP } & \text { Diisobutyl phthalate } \\ \text { DiDP } & \text { Diisodecyl phthalate } \\ \text { DiNP } & \text { Diisononyl phthalate } \\ \text { DMP } & \text { Dimethyl phthalate } \\ \text { DnBP } & \text { Di-n-butyl phthalate } \\ \text { DOP } & \text { Di-n-octhyl phthalate } \\ \text { E1 } & \text { Estrone } \\ \text { E3 } & \text { Estriol } \\ \text { ED } & \text { Endocrine disruptor } \\ \text { EDsA } & \text { Androgenic compounds } \\ \text { EDsE } & \text { Estrogenic endocrine disruptors } \\ \text { EDsT } & \text { Thyroidal compounds } \\ \text { EEQ } & \text { Estradiol equivalent } \\ \text { EFSA } & \text { European Food Safety Authority } \\ \text { ER } & \text { Estrogen receptor } \\ \text { ERBA } & \text { Estrogen receptor binding assay }\end{array}$




$\begin{array}{ll}\text { GSI } & \text { Gonadal somatic index } \\ \text { GSI } & \text { Somatic index } \\ \text { HIS } & \text { Hepatosomatic index } \\ \text { LOAEL } & \text { Lowest observed adverse effect level } \\ \text { NMDRC } & \text { Nonmonotonic dose-response curve } \\ \text { NP } & \text { Nonylphenols } \\ \text { NP1EO } & \text { Nonylphenol-mono-ethoxylate } \\ \text { NP2EO } & \text { Ethoxylate } \\ \text { OP } & \text { Octylphenols } \\ \text { PAHs } & \text { Polycyclic aromatic hydrocarbons } \\ \text { PBB } & \text { Polybrominated biphenyls } \\ \text { PCB } & \text { Polychlorinated biphenyls } \\ \text { PVC } & \text { Polyvinyl chloride } \\ \text { SS } & \text { Sewage sludge } \\ \text { STP } & \text { Sewage treatment plant } \\ \text { TCDD } & 2,3,7,8 \text {-Tetrachloridibenzo-p-dioxin } \\ \text { TDI } & \text { Tolerable daily intake } \\ \text { VTG } & \text { Vitellogenin } \\ \text { WTPs } & \text { Water treatment plants } \\ \text { WWTP } & \text { Wastewater treatment plants } \\ \text { YES } & \text { Yeast estrogen screen }\end{array}$

\section{Introduction}

The great variety of chemical compounds found in the environment may lead to many detrimental disorders in living organisms, due to the possibility of the interaction of these compounds with cellular components. Some of them can also induce hormonal responses, similar to those produced naturally by organisms.

Several natural and synthetic compounds, such as pharmaceutical drugs, pesticides, phytoestrogens, complex mixtures derived from effluents, some industrial wastes and several metals, can bind to estrogen receptors (Hilscherova et al. 2000). When compounds interact with estrogen receptors, they can interfere on the synthesis, secretion, transport, binding, action, or elimination of natural hormones, damaging the organic responses: blocking the effects of the hormones and promoting or inhibiting the endocrine system. The compounds that have these characteristics are called endocrine disruptors (EDs) (Rasier et al. 2006; USEPA 2011).

Campbell et al. (2006) cite many natural and synthetic compounds that act as EDs, among them are agrochemicals (atrazine, dieldrin, and toxaphene), surfactants (alkylphenol ethoxylates (APEOs)), natural hormones (17 $\beta$-estradiol (17 $\beta \mathrm{E} 2)$, estrone $(\mathrm{E} 1)$, and estriol (E3)), synthetic hormones (17 $\alpha$-ethinylestradiol (17 $\alpha$ EE2), diethylstilbestrol (DES)), and phytoestrogens (isoflavones and coumestrol). Moreover, other industrial compounds such as the bisphenol A (BPA), dioxin (2,3,7,8-TCDD), nonylphenols (NP), octylphenols (OP), phthalates, styrenes, polybrominated biphenyls (PBB), and polychlorinated biphenyls (PCB) (Diamanti-Kandarakis et al. 2010), and metals such as cadmium, lithium, barium, chromium, arsenic, and antimony are also inducers of alterations in the endocrine systems (Choe et al. 2003; DiamantiKandarakis et al. 2010).

Trudeau and Tyler (2007) separated the EDs in three different classes: androgenic compounds (EDsA), which mimic or block natural testosterone; thyroidal compounds (EDsT), which cause direct and indirect effects on the thyroid gland; and estrogenic compounds (EDsE), which mimic or block natural estrogen.

Estrogenic compounds are those that possess similar properties to the hormone $17 \beta \mathrm{E} 2$ (main natural estrogen produced by the ovaries), the effects of which are induced by interactions with the estrogen receptor and cell systems (Schug et al. 2011). In addition, according to Kiyama and Wada-Kiyama (2015), EDsE can act on two main pathways: the genomic path, linked to target gene transcription, and the nongenomic path, linked to signaling of specific membrane receptors. These contaminants are routinely present in the environment and can induce estrogenic effects, even at very low concentrations, causing reproductive and developmental disorders, both in humans and wild animals (Jugan et al. 2009). Due to the relevance, diversity, and complexity of adverse effects and chemical compounds related to estrogenic activity, only the EDsE will be discussed in this review.

Thus, the present review intends to carry out a concise approach regarding the main EDsE studied, describing their known effects and mechanism of action. Additionally, the most frequently used bioassays to detect estrogenic activities in different environmental samples will be also highlighted.

\section{Major Contributors to Estrogenic Activity in Environmental Samples}

Currently, many different chemicals have been recognized as potentially estrogenic; however, the EDsE may 
not be grouped by their chemical similarity since they present a high variety of chemical structures. According to Brzozowski et al. (1997), the presence of an aromatic ring in the structure is the only requirement to act as an effective ligand and bind to the estrogenic receptor.

Classical examples of EDsE that are frequently found in the environment, include natural and synthetic hormones and chemicals as BPA, phthalates, alkylphenols (APs), polycyclic aromatic hydrocarbons (PAHs), and agrochemicals.

BPA belongs to groups derived from diphenylmethanol and isophenol (Yang et al. 2015). In acid pH and high temperature, BPA results in a monomer that is used in the production of plastic and polycarbonates, which serve to fabricate plastic bottles, CDs, and DVDs (Chen et al. 2010; Kawahata et al. 2004; Staples et al. 1998; Sun et al. 2013; Vogel 2009). Several studies have established that BPA has the capacity to reduce the synthesis of steroid hormones (steroidogenesis) by the cortex of adrenal gland (Mandich et al. 2007). According to Bergeron et al. (1999), Letcher et al. (2005), and Levy et al. (2004), BPA mainly acts by interacting with estrogen receptors, by analogously operating and blocking the physiological activity of estrogen receptors or acting as antagonists of testosterone in the cell (Vagi et al. 2014).

Phthalates (diesters of phthalic acid) are synthetic chemical compounds widely used in medicine and industry (Department of Health and Human Services 2012) that may interact with organisms through ingestion, inhalation, or absorption (Chen et al. 2014; Meeker et al. 2009). Some phthalates, such as diethyl phthalate (DEP), di-n-butyl phthalate (DnBP), and diisobutyl phthalate (DiBP), are found in products for self-care, solvents, adhesives, and pharmaceutical drugs (Kelley et al. 2012; Sun et al. 2013; USEPA 2012). Others such as butylbenzyl phthalate (BBzP), di(2-ethylhexyl) phthalate (DEHP), diisononyl phthalate (DiNP), and diisodecyl phthalate (DiDP) are frequently used as plasticizers for the production of polymeric materials such as polyvinyl chloride (PVC) (Schecter et al. 2013; Stringer et al. 2000; USEPA 2012). Among the phthalates, DEHP is one of the most commonly found in the environment (especially in water) and in food. According Hsieh et al. (2012b), several studies have shown that phthalates are involved in the development of prostate and breast cancer, which is a consequence of the induction of abnormalities on endocrine functions and on steroid receptors. Some phthalates, as DnBP, present estrogenic activities that result in several alterations in the spermatogonia, spermatocytes, and spermatids, as well as inducing vitellogenin production in fishes (Bhatia et al. 2014).

APs are synthetic compounds constituted of antioxidants, modified polystyrene, surfactants, and PVC. Generally, they are present in various effluents and are constituted by different sized alkyl groups. The estrogenicity of those substances is related to the reduction in the alkyl chain size; in other words, the smaller the chain, the greater the estrogenicity (Oliveira et al. 2007; Servos 1999; USEPA 2006, 2010; White et al. 1994). The APs and their products, such as APEO, can affect the reproduction of organisms that are exposed to then because they mimic the estrogenic hormones that are responsible for development and sexual behavior. The NP, for example, mimic the natural hormone $17 \beta E E 2$ and compete with the endogenous hormones by binding to the ER (estrogen receptor) (Soares et al. 2008). According to Barber et al. (2015), NP is the AP with the major estrogenic effect.

PAHs are compounds generated from anthropic activities resulting from the incomplete combustion of fuels and certain industrial activities or even from natural sources, such as the formation of sedimentary rocks (Finkelman et al. 1999; Kavouras et al. 2001; Pleil et al. 2004). These compounds, including its metabolites, are considered highly toxic, mainly due to their physicalchemical characteristics (Tsay et al. 2013; Yamamoto et al. 2003). Van de Wiele et al. (2005) reported that PAHs can be bioactivated into estrogenic metabolites and show EE2-like activities. In general, the estrogenic activities occur through transcription factor activation (ER), which interact with response genes that are hormone-sensitive. However, only a few PAHs and their hydroxyl metabolites that have similar structures to estrogen are known to interact with ER (Fontenele et al. 2010; Nakata et al. 2014; Nesaretnam and Darbre 1997; Sievers et al. 2013). Therefore, there is discussion about how PAHs act as estrogenic substances: (1) with an estrogen-like action, duplicating the physiological effect; (2) by competing with hormones, inhibiting their effects; and (3) by indirect actions, changing the estrogen availability of target tissues (Santodonato 1997).

Several agrochemicals have a proven estrogenic activity (Pickford et al. 2015). This chemical group embraces a whole variety of chemical compounds; for this reason, the mechanism of action of endocrine interference is very diverse. According the review by Mnif et al. 
(2011), some agrochemicals may interact with hormone receptors and affect the cellular signaling pathway, whereas others may inhibit the activity of enzymes which are responsible for the synthesis of steroid hormones or even induce the enzymes responsible for this process, resulting in an increase or decrease in hormone levels (Kiyama and Wada-Kiyama 2015). Those interactions may also result in the formation of endocrinedisrupting metabolic products which are even more powerful than the original compounds (Andersen et al. 1999; Andersen et al. 2002; Astiz et al. 2014).

When evaluating the estrogenic activity of 200 pesticides belonging to different chemical groups, Kojima et al. (2004) observed that 51 were able to induce ERmediated transcriptional responses in Chinese hamster ovary cells. According to these authors, among the tested compounds, o, $\mathrm{p}^{\prime}$-DDT, $\beta$-BHC, $\delta$-BHC, methoxychlor, $\alpha$-endosulfan, dicofol, CNP-amino, prothiofos, cyanofenphos, and EPN showed the highest estrogenic activity. Kiyama and Wada-Kiyama (2015) also presented a long list of pesticides that are potentially recognized as EDsE, including aldrin, cyhalothrin, cypermethrin, deltamethrin, fenvalerate, glyphosate, permethirndiazinon, prothiofos pyriproxyfen, thiabendazole, and tolclofos-methyl.

Natural and synthetic estrogenic hormones also can be frequently found in the environment and, depending on the concentration, they can cause harmful effects to the exposed organisms. Hormones are defined as chemical substances synthesized by the endocrine glands, which when released in the blood stream, maintains a balance in the functioning of the whole organism (Bila and Dezotti 2007; Díaz-Cruz et al. 2003; Ghiselli and Jardim 2007; Shimada et al. 2001; Srivastava 2015).

Among the natural estrogens, three categories stand out: (1) steroid hormones like $17 \beta$-E2, the primary female sex hormone, besides the E1 and E3, which are major female endogenous estrogens that exert estrogenic hormonal activity; (2) phytoestrogens, such as isoflavones, genistein, and daidzein, which are polyphenols with estrogen-like structure and function, found naturally in plants and, consequently, in many foods (Lezcano et al. 2017; Morissette et al. 2018), whose presence in the environment occurs predominantly due to agricultural sources; (3) mycotoxins, such as zearalenone and zearalenol, that are nonsteroidal estrogenic compounds produced by fungi belonging to the genus Fusarium and Gibberella (Ghiselli and Jardim 2007;
Lintelmann et al. 2003; Shimada et al. 2001; Shore et al. 1993; Yang et al. 2007).

Synthetic estrogen hormones, as for example, mestranol, DES, and $17 \alpha \mathrm{EE} 2$ (Wenzel et al. 1998), are artificial compounds used as pharmaceuticals in contraceptive and in hormone replacement therapy formulations that due their high use are widely found in the environment (Darbre 2015).

Among the harmful effects caused by exposure to the natural and synthetic hormones are alterations in reproduction such as infertility, menstrual irregularities, miscarriages, and breast cancer. In ecosystems, exposure can cause sex reversal in fishes and other animals (Bhatt 2000; Sweeney et al. 2015). Both the natural and synthetic hormones undergo biotransformation before being excreted by the organism. It is known that $60 \%$ of these drugs are excreted in the urine as conjugates and several polar metabolites. The most common dissemination paths of these hormones are domestic effluents discharged into rivers and seas, deficiency in the sanitation infrastructure or by the inefficient treatment of these effluents, resulting in major environmental contamination (Erickson 2002; Gilman et al. 2003; Sweeney et al. 2015).

Nevertheless, in the environment, EDsE and natural and synthetic hormones are generally found in a complex mixture of different chemical nature. These agents may interact with each other, often forming compounds whose negative effect on the exposed organisms is greater than that observed for each individual compound in the mixture. According to Payne et al. (2000, 2001), some studies have shown that even if some components of a mixture are in concentrations that do not cause individual effects, a synergistic effect may be observed for the mixture due to the combination of the components. In some studies, authors have reported different effects resulting from the interaction between EDs, such as additives, synergists or antagonists (Barouki 2017).

Although $95 \%$ of the studies performed with these compounds are still done with isolated substances, the study of the interactions between EDsE becomes more relevant because the exposure to them usually occurs in complex mixtures, generally derived from effluents discharges (Kortenkamp 2007). However, Sun et al. (2009) and Zhou et al. (2017) highlight the absence of effective techniques to evaluate the interaction between EDs, mainly due to the differences between the chemicals belonging to this group. 
Studies performed by Charles et al. (2002) showed that mixtures contained $17 \beta \mathrm{E} 2,17 \alpha \mathrm{EE} 2$, and DES present additive effects when each compound is present at levels in the linear range of their individual doseresponse curves. However, in higher concentrations, the effect is lower than expected. According to the authors, such effect is due to a saturation event.

Given the paucity of data on the effects of the combination of EDs, studies intended at evaluating the impact induced by the mixture of these compounds must be encouraged, since this kind of exposure points us to the real situation of exposure to EDs, which in most cases are not found isolated in the environment.

Moreover, due to their easy release and high prevalence in the environment, added to their difficult removal by common treatments and bioaccumulation at different trophic levels, there is an urgent need to reduce or optimize the use of compounds that can act as endocrine disruptors, and mainly generate public policies aimed at reducing their use and to improve the techniques of treatments that may prevent these compounds from reaching the environment.

\section{Effects Induced by Estrogenic Agents}

Compounds with estrogenic properties are used in excess in several areas, meaning that substances can be found in all types of environments (Niemuth and Klaper 2015). As a result of the persistence and bioactive characteristics of these substances on soil and hydric resources (Halling-Sorensen et al. 1998; Meyer et al. 1999), the compounds with estrogenic activities can be considered environmental pollutants that may contaminate the entire food chain. Besides environmental contamination, humans can be exposed to these compounds by occupational pathways, during production, use or waste (Baccarelli et al. 2000; Ying 2012).

\subsection{General Effects}

Estrogenic agents present in the aquatic ecosystem can result in a major population imbalance of several animal species. The continuous exposure in the long term to these substances, even if at minimal concentrations, may compromise the existence of endemic species at contaminated locations, because those compounds are able to induce male feminization and infertility in exposed organisms (Cavallin et al. 2016; Gorga et al. 2015; Vajda et al. 2008). Furthermore, when those substances come into contact with females, effects can be even worse, because of the possible transmission to eggs, the placenta and breast milk, therefore exposing all descendants to this, and ultimately interfering with the development of the offspring (Bila and Dezotti 2007).

The effects of estrogens present in the water on organisms depend on the exposure time. Fishes, for example, are more significantly affected by hormones than humans, because they are constantly in contact with water (Snyder et al. 2003). However, Baldigo et al. (2015) stated that exposure to low levels of EDsE can affect organisms at the top of food chain, as a result of the bioaccumulative character of these substances. In female fishes, the presence of estrogen in the water can be identified by means of early vitellogenesis (Jones et al. 2000) or by plasma level alterations of vitellogenin (precursor protein in calves, where liver production is stimulated by estrogen). Both male and female fishes have estrogen receptors, but only females are normally exposed to natural estrogens (Baldigo et al. 2015). Consequently, when nonvitellogenic male and female fishes are found which produce vitellogenin, there are signs of estrogen present in the environment (Kime et al. 1999). The induction of vitellogenin in male fishes is related to a decrease of plasmatic testosterone (Hashimoto et al. 2000; Mills et al. 2001), renal and gonadal pathology, and ovary follicles on testicles (Simpson et al. 2000). Anderson et al. (2003) and Okoumassoun et al. (2002) confirmed that vitellogenin presence in male fishes can lead to reproductive problems, such as reduced fertility, which may promote alterations in the population density of river fishes.

Another parameter which indicates the presence of EDsE in environment is the existence of intersex animals (Liney et al. 2006; Niemuth and Klaper 2015); in other words, dioic individuals that presented sexual characteristics of males and females simultaneously (Kelly et al. 2004). The studies of Jobling et al. (2002) and Osman et al. (2015) showed that intersex decreased the fertility of Rutilus rutilus males, resulting in gametes with low motility and, furthermore, low ability for fertilization and decreased viable descendant production.

Pimentel et al. (2016) characterized the morphofunctional parameters of the tropical fish Sphoeroides testudineus and investigated the eventual occurrence and disruptive endocrine effects on Pacoti River (Ceará, Brazil). Collected fishes were weighed, measured and dissected for the evaluation of gender 
(male, female, indeterminate) and histological and vitellogenin analyses. The gonadal weight of indeterminate fishes was significantly lower than that of males and females. Although differences in gonadal weight were observed, the gonadal somatic index (GSI) showed different standards only between males and the other two groups analyzed (female and indeterminate). The authors also reported that the expression of vitellogenin (VTG), which was identified in several mature males and indeterminate fishes, indicated endocrine dysfunction. The EDsE were identified and quantifies (E1, $17 \alpha \mathrm{E} 2,17 \beta \mathrm{E} 2,17 \alpha \mathrm{EE} 2$, DES, and E3) in sediment from river spots. Those results were considered indicative of river involvements by contamination with estrogenic compounds. Specimens of Mullus barbatus fish were exposed to water of the northwest Mediterranean region, which suffered the impact of sewage treatment plant (STP) effluents; those fishes presented high concentrations of NP (average of 0.34 to $28.31 \mu \mathrm{g} / \mathrm{g}$ ) and OP (0.03 to $0.25 \mu \mathrm{g} / \mathrm{g}$ ) in bile. The individuals also presented gonadal alterations, such as hypertrophy of connective tissue, fibrosis, necrosis, intersex, and delay in the maturation process of gametes (Martin-Skilton et al. 2006). Several authors have correlated the presence of higher levels of NP in water with intersex and vitellogenin in male fish (Jobling et al. 1998; Lavado et al. 2004). However, some gonadal alterations observed by Martin-Skilton et al. (2006) did not arise from the presence of polyphenols, but may come from a mixture of urban and industrial contaminants, including PCB.

Several species of fish, including Cyprinus carpio, Micropterus spp., and Ictalurus punctatus, collected at different points of the Colorado River (EUA), showed reproductive disorders like intersex (males with testicular oocytes and females with sperm in the ovaries), changes on the plasmatic vitellogenin in males and females, as well as underdeveloped gonads in males. At regions of the Colorado River, the percent of intersex males reached $70 \%$ (Hinck et al. 2007). In their article, the authors mention various works which report the presence of high concentrations of metals and organochlorine pesticides, such as DDT and its metabolites, in water, sediment, and river-associated biota. The estrogenicity of organochlorine pesticides, such as lindane, dieldrin and heptachlorine, was confirmed by Okoumassoun et al. (2002), who verified the production of vitellogenin in male fish from the species
Sarotherodon melanotheron living in Ouémé River, Republic of Benin, Africa, which is contaminated with these pollutants.

In a study performed by Moresco et al. (2014), the authors recorded malformations in the gonads of frogs Physalaemus cuvieri found in the south of Brazil. They collected and removed the testicles from 20 males. By histological analysis, they observed the presence of both sperm and oocytes in 4 of the 20 analyzed specimens. The chemical analysis of water samples of the place confirmed the presence of organochlorines, organophosphates, and carbonates. Among the pesticides identified, only Dieldrin was found at values above those permitted by Brazilian law. The authors assumed that this high presence of this organic compound can be due to its cumulative potential.

The transference of EDs to humans occurs mainly by the consumption of aquatic animals which may have bioaccumulated EDs, as well as by the ingestion of drinking water arising from rivers that receive chemical residues, which mimic the effects of estrogen (Maurício et al. 2006).

Although man sits at the top of the food chain and is able to ingest high amounts of estrogenic compounds, which bioaccumulate in other organisms, the estrogenic effects that humans are subject depend on the toxicological properties of the contaminants and their synergistic or antagonistic in vivo effects, on their concentration and on the rate of consumption of directly exposed organisms, like fish (Pinto et al. 2008).

In human beings, the main effects of estrogenic compounds include the reduction in sperm quantity, and an increase in the occurrence of breast, testicular and prostate cancer and endometriosis (Bila and Dezotti 2007). According to Mueller (2004), estrogen receptors in the human body can be expressed in the reproductive system, mammary glands, kidneys, liver, bones, adipose tissue, immune and cardiovascular system, brain, and lungs.

Although human exposure to synthetic estrogen usually occurs at low levels, these compounds tend to accumulate in the adipose tissue of the organism as a result of its lipophilic character and its nonimmediate metabolism. In this way, breast cells, which are localized in a fatty region, become targets for cancer development (Darbre 2001). Knower et al. (2014) state that there is a strong relationship between the exposure to EDsE and breast cancer development. The authors reported that different types 
of EDsE, like BPAs, synthetic estrogen, DES, PAHs, and the pesticides 2,3,7,8-tetrachloridibenzo-p-dioxin (TCDD), DDT, and vinclozolin, for example, are involved in the development of breast cancer in direct and indirectly exposed women and other female animals, as mice and Rhesus monkeys.

In vertebrate animals, the action of EDsE can be mediated by receptors. When this receptor interacts with strength, a signal is sent to the nucleus of the cell, which stimulates the synthesis of specific proteins (Harvey and Johnson 2002; Shaw and McCully 2002). These sites can be occupied by xenobiotics, which have similar chemical features to estrogens, acting by analogy or blockage of the natural hormones, binding to specific sites and causing undue responses, such as an excess or lack of certain proteins (Jacobs 2001; Shaw and McCully 2002). Another mechanism of action of EDsE is the interference of the enzymatic sequence, which leads to the premature elimination of hormones, the deactivation of breakdown enzymes or incapacitation (by destruction or inactivation) of the execution of hormonal activities (Harvey and Johnson 2002; Janošek et al. 2006; Shaw and McCully 2002).

\subsection{Epigenetic Effects}

During the process of growth and development of an organism, some EDs may activate or deactivate some genes in specific locations of the genome by means of epigenetic mechanisms (Shahidehnia 2016). Epigenetic mechanisms can be defined as inheritable changes in gene expression, without alteration in the DNA sequence. Thus, phenotypic alterations but not genotypic can be observed (Buckland 2015). Several studies have correlated the epigenetic effects of ED exposure with an increase in the incidence of breast cancer, reproductive disorders, abnormal growth patterns, defects in neurological development in children, and modifications in immune system (Shahidehnia 2016).

Epigenetics plays an important role in cell differentiation, growth, metabolism, and regulation of gene expression through the silencing and activation of specific genes (Bernstein et al. 2007; Esteller 2007; Jirtle and Skinner 2007). The major epigenetic modifications include DNA methylation, posttranslational modifications of histone proteins, and alterations associated with noncoding RNAs (ncRNAs) (Tammen et al. 2013).

There is a great concern about exposure to EDsE during development since epigenetic modification will be transferred to subsequent generations by germline in a process termed transgenerational epigenetic (Zama and Uzumcu 2010).

A very representative example of inheritance of the effects induced by the ED exposure is the case of DES. This synthetic nonsteroidal estrogen was widely used by millions of pregnant women to prevent miscarriages in the 1970s. Among the adverse effects induced in men and women born from exposed mothers to DES are breast cancer, reproductive tract cancer, prostate cancer, infertility, and many others reproductive disorders (Shahidehnia 2016).

Hsu et al. (2009) evaluated the effects of the DES in in vitro breast epithelial cells and observed a downregulation of miR-9-3 (microRNA associated with breast cancer) and repressive chromatin marks as $\mathrm{H} 3 \mathrm{~K} 27 \mathrm{me} 3$ and $\mathrm{H} 3 \mathrm{~K} 9 \mathrm{me} 2$. These modifications were accompanied by recruitment of DNMT1 that caused an increase in DNA methylation of the promoter $\mathrm{CpG}$ island. According the authors, the hypermethylation of this microRNA may be a mark for early breast cancer development.

Some pesticides may also cause harmful effects by epigenetic mechanisms. Milesi et al. (2017) exposed newborn female rats at 6 or $600 \mu \mathrm{g} / \mathrm{kg} /$ day of endosulfan every $48 \mathrm{~h}$ on postnatal days to 1 from 7 . When sexually mature, the rats became pregnant and on the fifth day of gestation, uterine samples were collected. The results showed that neonatal exposure to endosulfan increases the expression of ER $\alpha$ during the preimplantation period. This finding was correlated with a predominant hypomethylation of $\mathrm{CpG}$ islands of the ER $\alpha$ promoters observed in the uterus. Thus, the authors suggest that epigenetic changes mediated by methylation are one of the possible mechanisms by which endosulfan causes subfertility. In previous studies, Milesi et al. (2015) have demonstrated that low doses of endolsulfan induces subfertility in female rats, characterized by a drop in the pregnancy rate and in number of implanted embryos. In addition to these effects observed by Milesi et al. (2015, 2017), endosulfan may also cause uterine changes (Varayoud et al. 2008) and affect male and female postnatal reproductive development (Lafuente and Pereiro 2013; Milesi et al. 2012).

The plasticizer butyl benzyl phthalate (BBP) is an ED whose effects are correlated with high risks of endometriosis (Upson et al. 2013), several reproductive disorders in male (Foster 2006) and breast and prostate cancer (Hsieh et al. 2012a). Kang and Lee (2005) 
evaluated the mechanism of action of BBP in human breast cancer MCF7 cells and found an increase in ER $\alpha$ mRNA expression levels and a demethylation of ER $\alpha$ promoter-associated $\mathrm{CpG}$ islands. From these findings, the authors suggest that the modifications in ER mRNA expression by BBP might be related to abnormal DNA methylation in the promoter region of $\mathrm{ER} \alpha$.

BPA is another ED that has demonstrated to induce epigenetic effects. According Manikkam et al. (2013), exposure to BPA may induce early puberty, prostate disease and cancer, mammary abnormalities including pre-neoplastic lesions, disorders in uterus and ovaries. Liu et al. (2017) evaluated the effects of BPA on ovary and eggs from female mice and found that this estrogenic compound acts mainly via modifications in histone acetylation, and it can affect the oocyte maturation, fertilization rate, and early embryonic development. The authors observed an upregulation of HDAC1 mRNA levels and a downregulation of HDAC5 and HDAC7 mRNA levels in egg and ovarian tissues. Among the class II HDACs, HDAC7 was the most sensitive target of BPA and it was considered an important element in epigenetic maintaining during the process of egg development.

Benzopyrene exposure is associated with pregnancy loss, alterations in fetal development (Zhang et al. 2016), alterations in weights of the reproductive organs, damage in ovarian follicles, and infertility and abnormal fetal development in laboratory animal models (Borman et al. 2000; Csaba et al. 1993; MacKenzie and Angevine 1981; Rigdon and Rennels 1964). Analysis of epigenetic effects of benzopyrene was studied in four breast cancer cell lines (MCF-7, T47-D, MDA MB 231, and HCC-1806) by Sadikovic and Rodenhiser (2006). Analysis of DNA methylation indicated altered DNA methylation patterns suggesting that benzopyrene may lead to dynamic, sequence-specific patterns of hypo- and hypermethylation in all four cell lines analyzed and reinforced the relation between benzopyrene exposure, DNA methylation and breast cancer.

The isoflavonoid genistein is an ED whose uterine or neonatal exposure is correlated to induction of several effects in female mice as reproductive disorders (Drummond and Fuller 2010; Patisaul 2009), increase in ano-genital distance (masculinization), accelerated puberty and irregular estrous cycles (Jefferson et al. 2005). Preconception exposure to genistein also affects gestation time, parturition time, litter size, pup weight, and pup mortality in mice (Patel et al. 2017). According to Whirledge et al. (2015), genistein can modulate the ER activity, leading to the development of various uterine pathologies in humans. Yu et al. (2016) found that the exposure of human uterine leiomyoma cells to genistein leads to an upregulation of genes involved in cell proliferation and tumorigenesis. Genistein exposure induced epigenetic regulation of transcription factor promoter regions by a mitogen-activated protein kinase (MAPK p44/42) through mitogen- and stress-activated protein kinase (MSK1) and histone $\mathrm{H} 3$ phosphorylation at serine 10 site. These results demonstrate that ginestein is a compound that may regulate the transcription of certain genes correlated to cancer induction through epigenetic mechanisms by histone phosphorylation.

As can be seen from the examples above, exposure to EDsE may alter the epigenetic programming of an individual and cause important modifications in the expression of genes associated with various diseases, including cancer and problems of reproductive order. Furthermore, exposure to some EDs during gestation and the early stages of development may lead to epigenetic modifications that can be transmitted to future generations and interfere with the normal development of the offspring.

Since that epigenetic mechanisms are reversible events, knowing the mechanism of action of the EDs upon the cells and more specifically upon the genetic material of organisms, is an important step, if not fundamental, in the improve and development of new techniques to combat and/or prevent diseases such as cancer as well diseases affecting female and male reproductive systems that may compromise the next generations.

Currently, studies on epigenetic drugs are being conducted and many of them are already in the test phase. With this, not only the individual directly exposed to EDs could be benefited, but also their offspring.

\subsection{Nonmonotonic Dose-Response Curves for Endocrine Disrupting Chemicals}

Recently, many studies have been pointing out that the EDs do not exhibit a typical dose-response relationship, where an increase in their concentration leads to a proportional increase in the observed response until reaching a maximum limit, resulting in a sigmoid curve. In contrast, for the majority of the EDs a nonmonotonic dose-response curve (NMDRC) has been frequently observed (Gioiosa et al. 2015; Lagarde et al. 2015; Vandenberg 2014a). By definition, an NMDRC or a 
biphasic dose-response curve represents a doseresponse relationship characterized by modifications in the slope directions over the interval of tested concentrations (Beausoleil et al. 2013). In this relationship, the most prominent results are observed in intermediate concentrations range, resulting in an inverted- $U$ shaped curve; or when the lowest and highest tested doses induce the highest effects, producing a U-shaped curve.

Lagarde et al. (2015) reported in an extended review that more than 170 EDs showed an NMDR profile when evaluated in studies in vitro and in vivo. Among the substances, BPA, followed by the $17 \beta \mathrm{E} 2$, were the most studied ones, inducing several physiological effects in different organs (mammary and pituitary glands, liver) and systems (reproductive, cardiovascular, immune). According to these same authors, two main mechanisms were often cited to justify the NMDR relationship observed in the studies. The first one is related to the affinity of a same ED to bind to different molecular targets (e.g., different receptors), which exhibit oppositive effects when activated. In this case, in low concentrations, only one receptor would be activated (probably the one with more affinity with the ED), but, in higher concentrations, more types receptors can be activated and then, to inhibit the effect observed for the low tested concentrations. Thus, the absence of an increased response in higher concentrations leads to the formation of an NMDRC. The second mechanism proposed is the occurrence of negative feedback system to regulate the concentrations levels of hormones, avoiding an increased response in high concentrations of EDs. Vandenberg (2014a) also mentioned the overlap of effects caused by an ED to explain the occurrence of an NMDRC profile, such as the induction of cytotoxicity or cell proliferation inhibition associated with estrogenic activity response. For these specific cases, higher concentrations would lead to an absence of estrogenicity due to the cytotoxic effect or inhibition of proliferation.

\subsection{The Low-Dose Effects Concept for EDs}

Another important concept strictly related to the EDs is called "low-dose effects." This principle is based on the fact that endocrine hormones circulate and operate at very low doses, in nanomolar and, even, picomolar levels. Thus, it is expected that the EDs may exhibit biological response at similar doses (Vandenberg 2014b). Additionally, specifically for the EDs, the lack of observed effects at high tested concentrations cannot be representative of the expected results at low tested doses, as in the classical toxicology (Nadal et al. 2018).

According to Melnick et al. (2002), a low-dose effect can be defined as any biological alteration induced by EDs in low concentrations. Moreover, the concentration ranges must represent a high environmental relevance, causing disorders even in concentrations below the lowest observed adverse effect level (LOAEL), which was determined in the previous studies (Vandenberg et al. 2012).

Many studies corroborate the low-dose effect for the EDs, and it seems to be the new trend in this field of research. Vandenberg et al. (2012) showed in a review that almost 30 EDs, belonging to different chemical groups (pesticides, synthetic hormones, phytoestrogen, detergents, plasticizers, UV blocker, flame retardant, and others involved in several industrial processes) presented significant results for endocrine activity when tested in low doses, providing pieces of evidence for the low-dose hypothesis. However, although some advances were obtained in this sense, the great majority of data is related to few substances, such as BPA. A review conducted by vom Saal and Welshons (2006) about the effects of BPA in low concentrations reported the presence of more than 100 studies showing significant effects for this chemical when tested in concentrations below the LOAEL. In a recent study, Lejonklou et al. (2017) observed alterations in the lipid metabolism in rats caused by developmental exposure to a BPA concentration eight times lower than the tolerable daily intake (TDI) established by the European Food Safety Authority (EFSA). Other studies also observed a lowdose effect for BPA inducing neurological disorders in zebrafish embryos (Kinch et al. 2015) and physiological impairments in mice (Gioiosa et al. 2015).

Although the low dose effects concept and the NMDRC can be interrelated, they cannot be confused, since they present distinct definitions and mechanisms involved. However, both must be taken into consideration when conducting toxicological studies with ED compounds. Furthermore, the NMDR relationship is not restricted to the low tested doses (Vandenberg 2014b).

Thus, from what it has been reported here, it is evident that the EDs represent a challenging field of research and still require more study. Many safety exposure limits of EDs, previously established by regulatory agencies, must surely be revised, especially because the observed effects can differ along the concentrations range and low concentrations can exert relevant effects 
to the organisms even when the higher concentrations do not cause any effect. Additionally, specific data regarding the presence or absence of NMDR pattern and the low-dose effect are missing for a major number of EDs. Moreover, long-term exposure studies and the effects of interactions among EDs in complex mixtures must be considered in future researches due to their expressive environmental relevance. Finally, these facts must demand new efforts to perform an adequate risk assessment for the EDs.

\section{Studies for the Detection of Estrogenic Activity in Environmental Samples}

Rivers and their sediments are the major reservoirs of the EDsE, being responsible for many alterations in aquatic ecosystems because they act by destabilizing the normal functions of the exposed organisms. The estrogenicity verified in water and sediments of the aquatic systems is mostly related to the dumping of effluents from domestic, industrial (Dias et al. 2015; Li et al. 2008), agricultural, and livestock (Verderame et al. 2016) activities. For example, the domestic effluents are composed by a great diversity of chemical substances present in cleaning products and drugs, as well as natural hormones that are discharged or excreted directly into the environment (Dias et al. 2015). In the USA, many pharmaceutical drugs, including the hormones present in oral contraceptives, have been found in almost every analyzed river (Kolpin et al. 2002), with concentrations that are sufficient (normally in $\mathrm{ng} / \mathrm{L}$ ) to cause estrogenic responses in exposed animals (Gorga et al. 2015; Petrovic et al. 2001). Moreover, factors such as temperature and microbial activity can alter the estrogenic activity of an environment (Hemming et al. 2004), as compounds including estrogen and NP can be degraded by microorganisms in rivers, sediments and soil (Hseu 2006; Yin et al. 2002; Ying et al. 2002).

Many researches have been performed to identify the presence of EDsE under the most varied environmental matrices. In this regard, there has been a great effort in developing assays that can determine the presence of EDsE in environmental samples and, also, to detect which concentrations of these substances can have harmful effects on living beings. Thus, based on reports from the scientific literature, this section describes some bioassays that have been used satisfactorily in the evaluation of estrogenic activity in different environmental samples, particularly in surface water, sediments, effluents, and sludge.

\subsection{Sewage and Wastewater Treatment Plant (WWTP)}

Residual waters derived from both water and sewage treating constitute a great concern with regard to the introduction of estrogenic contaminants into the environment, mostly because traditional methods conventionally used by wastewater treatment plants (WWTPs), such as dredging (removal of floating particles and solids of bigger dimensions), adsorption and decantation (removal of the resulting primary sludge), and aerobic and/or anaerobic degradation (Fontenele et al. 2010; Lester and Edge 2001; Rosa 2008), are inefficient and need to be reevaluated (Rosa 2008). Besides, with WWTPs, the transformation of substances present in the effluents, many times, results in higher levels of reactive compounds than at the initial sewage and, when they are discharged into the aquatic environment, they may induce estrogenic responses in many animals (Folmar et al. 2002). Nonionic surfactants, such as alkyphenol polythoxylates, when degraded by metabolic processes in WWTPs transform into NP or OP (Arukwe and Goksøyr 2003; Bennie et al. 1997), which induce the production of vitellogenin in male organisms of various fish species (Jobling et al. 1998; Schwaiger et al. 2000). Additionally, EDsE can also be found in sewage sludge since, according to Urase and Kikuta (2005), a large part of these compounds is transferred from the liquid effluent to the sludge during sewage treatment.

Gou et al. (2016) combined chemical measurements and bioassays to evaluate the presence and risks of EDsE in seven WWTPs located in north, south, and central Taiwan, from 2011 to 2012. In this study, the E-screen, which quantifies MCF-7 breast cancer cell proliferation induced by EDsE and T47D-Kbluc, a cell-based reporter gene assay with T47D human breast adenocarcinoma transfected with estrogen-responsive luciferase reporter gene, were performed to detect total estrogenic activity. The authors observed, in all studied samples, a higher detection rate of DEHP $(82.1 \%)$ than other compounds. The bioassays performed in the first collection showed that, of the 56 studied samples, 23\% presented significant amounts of estradiol equivalent (EEQ), being the E-screen the most sensitive assay. Thus, the authors concluded that the combination of Escreen and chemical analysis can grant a good strategy for EDsE detection in environmental samples. 
The influents and effluents of four different domestic WWTPs and the effluent of a bleaching pulp industrial site were evaluated by Fernandez et al. (2007) in terms of chemical compositions and estrogenic activity. Among the found substances, 19-noretindrone was the most abundant synthetic hormone in the influents, while $17 \alpha \mathrm{EE} 2$ was the most frequent synthetic hormone in the studied effluents. The synthetic nonsteroids NP and DEHP were present at high levels in both wastewaters and treated waters (effluents) and nontreated waters (influent). Domestic effluents showed superior amounts of steroids estrogens when compared to industrial effluents, which mainly contain the plant steroid stigma sterol. The variation in EDsE found in the samples is related to the different substances being used in each treatment. In the case of domestic WWTPs, 19noretindrone was present because it is the most frequently used synthetic hormone for birth control in Canada, while, in the case of the effluent from the bleaching pulp site, plant steroids were found due to their release during wood processing. By using the in vitro assay with recombinant yeast carrying the human estrogen hormone receptor (ER-RYA) to detect receptor binding affinity in the samples, similar values of EEQ to domestic and industrial effluents and higher values than influents were observed. The authors concluded that, although the estrogenic activity is mainly related to domestic effluents due to the presence of steroid estrogens, the high levels of phthalate esters and natural steroids also can contribute to this effect.

The analysis of an industry effluent in Taiwan that processes products derived from fossil fuels (like plastic) using the MVLN assay confirmed the presence of compounds with estrogenic activity. This assay employs the MVLN cells (a cell line derived from MCF-7 cell, with estrogen-specific transcription and a reporter gene that produces luciferase in the presence of estrogen) to identify estrogenic activity related to all pollutants by the detection of luciferase activity verified with the aid of a luminometer. The estrogenicity values varied between 0.54 and $47.86 \mathrm{ng}$ EEQ/L, and the highest values were probably related to the presence of phenols (Chen et al. 2004). According to the authors, the relative quantity of estrogenicity found in analyzed industrial effluents may signify the environmental risk in the case of these effluents being discharged without previous efficient treatment.

Cargouët et al. (2004) performed the estrogenic activity evaluation of influent and treated effluent samples from WWTPs around Paris, France, by in vitro bioassays with MELN cells (an estrogen-responsive human cell line). These cells present a luciferase reporter gene placed under the control of estrogen-responsive elements to enable to assess the induction of the estrogen hormone receptor $\alpha(\operatorname{Er} \alpha)$-mediated gene expression. In this study, the authors evaluated two different classes of pollutants (polar and nonpolar substances). They observed the estrogenic activity only in samples with the presence of nonpolar substances, indicating that most of the contaminants with estrogenic activity are nonpolar.

Jugan et al. (2009) also used the MELN cell line in order to verify the estrogenicity induced by influents and effluents of two STPs and by surface waters from the Seine River (Paris, France). Efficiency superior to $90 \%$ was observed for both WWTPs with relation to the decreased estrogenic activity. However, an increase in estrogenicity of the river waters was detected after effluent disposal (2.5 ng/L of EEQ for STP-A and $2 \mathrm{ng} / \mathrm{L}$ for STP-B). These observed values constitute a risk for ecosystems, in particular aquatic ones, because at these concentrations, or even lower ones, they can compromise the endocrine functions of exposed organisms.

The analysis of effluent samples from the Apulia region, Italy, before their treatment in STPs, revealed the presence of E1, $17 \beta \mathrm{E} 2,17 \alpha \mathrm{EE} 2, \mathrm{BPA}$, and $\mathrm{OP}$. Among these compounds, BPA (103.4 ng/L) and OP $(35.2 \mathrm{ng} / \mathrm{L})$ showed the highest concentrations on average, followed by E1 (32 ng/L), 17ßE2 (23.6 ng/L), and $17 \alpha$ EE2 (17.6 ng/L). In this study, Balest et al. (2008) stated that, although the estrogenic activity of industrial activity derived compounds is lower than that of natural steroids, they can induce comparable effects to natural estrogens, due to the high concentrations that they are found at in the environment (usually ng/L for estrogens and at least $\mu \mathrm{g} / \mathrm{L}$ for industrial compounds).

In natural wastewater arising from urban and industrial activities in Zagreb (Croatia) were studied in terms of their estrogenic potential, using vitellogenin induction in rainbow trout hepatocyte cultures (Oncorhynchus mykiss) (Grung et al. 2007). Among the 30 tested fractions obtained by solid phase extraction, 9 induced an increase in the amount of vitellogenin. The authors attributed the observed effect to the presence of E2 and E3, as well as to different APs, benzophenones and methylparabens.

Salste et al. (2007) investigated the presence of estrogens and the estrogenic activity of a domestic effluent of Turku/Åbo (Finland), by chemical analyses and by 
the bioluminescent yeast assay (containing estrogen receptor $\alpha(\operatorname{Er} \alpha)$ and the luciferase constitutive gene (Ffluc)). The data indicated estrogenicity values from 4 to $7 \mathrm{ng} / \mathrm{L}$ of EEQ. This effect was mainly attributed to the presence of E1, since this was the most abundant estrogen found in the studied samples.

Sludge derived from water treatment plants (WTPs) and WWTPs, as well as the resulting biosolids from stabilization processes of these sludges, can constitute a source of EDsE in the environment. As the sludge and the biosolid are compounds which are rich in organic matter, their use as agricultural fertilizers has been suggested. However, Yamamoto et al. (2003) warned that the use of these materials in agricultural practices can contaminate the soil and groundwater with estrogenic substances, because of hydrophobicity coefficients and the moderately high organic carbon partition of estrogenic compounds, which means that a large part of these substances stay bonded to solid phase during the treatment process of WTPs and WWTPs.

In this sense, Mazzeo et al. (2016) evaluated the organic and aqueous extracts obtained from naturally attenuated sewage sludge (SS) as to its estrogenic potential by means of yeast-based bioassays (ER-RYA). However, the results did not show substantially estrogenic activity in samples in the initial period, which significantly decreased after attenuation. The authors state that the data found in this study support the efficiency of natural attenuation and potential of the use of SS for agricultural purposes.

Giudice and Young (2011) studied, on a pilot scale, the estrogenicity of leachate and surface runoff water of soils fertilized with biosolids, for six different EDsE. In this study, $17 \alpha \mathrm{EE} 2$ and BPA were not detected in any of the samples. N-NP and triclosan were only present in runoff water. Despite the substances triclocarban and OP being present both in runoff water and leachate, the high registered concentrations were found in runoff water. The author still observed, by the chemical-activated luciferase gene expression ER-CALUX bioassay, a higher estrogenic activity to samples corresponding to

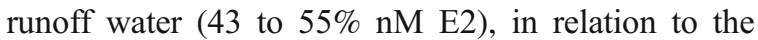
referent leachates (15 to $42 \% \mathrm{nM} \mathrm{E} 2$ ).

\subsection{Aquatic Environment}

Environmental pollution by estrogenic compounds is not only due to the resulting effluents from treatment processes, but also from direct discharges with estrogenic action along the riverbank, mainly because of domestic activities (Ma et al. 2007). In these cases, the levels of EDsE are, in general, much higher, and can contribute to a drastic increase in the estrogenic potential of waters. On the other hand, when there is no other effluent discharge along the river, these compounds tend to be diluted during their path, consequently decreasing their absorption availability by aquatic organisms (Maurício et al. 2006) and their estrogenic effects (Hemming et al. 2004). Due to the constant presence of EDs in aquatic environments, as reported by the following studies, much attention must be given since they can represent a potential risk to exposed organisms.

In a monitoring study performed between 2010 and 2012 by Selvaraj et al. (2015), the authors evaluated the presence and the ecotoxicological risks of ester phthalates found in surface water and sediment samples collected from the Kaveri River (India). During the study period, the presence of diethyl phthalate (DEP) and dimethyl phthalate (DMP) was observed in all samples; however, the results showed that the percentage of phthalates found in the river did not present risks to human health, based on drinking water consumption. Further, according to the chronic values of ECOSAR software, the water quality presented little threat to the sensitive organism regarding the presence of DEHP and di-n-octhyl phthalate (DOP). For the sediments, the evaluation indicated that DEHP was the residue which presented the greater concern to the environment.

Zhao et al. (2011) reported multiple hormonal activities, among them the estrogenic activity in surface water and sediments of the Pearl River basin (Liuxi, Shijing, and Zhujiang Rivers) south of China. By applying the estrogen receptor reporter gene assay YES (yeast estrogen screen), the authors found estrogenic activity levels that varied from 0.23 to $324 \mathrm{ng} / \mathrm{L} \mathrm{EEQ}$ in surface waters and from 0 to $101 \mathrm{ng} / \mathrm{g}$ EEQ in sediments. Shijing River presented higher levels of hormonal activities than Zhujiang and Liuxu rivers, indicating that it receives a greater influence of chemical products regarding the action of EDs. The EEQ concentrations observed in this study were higher than those considered in the literature as being responsible for adverse effects on aquatic organisms, confirming the commitment of the studied water bodies regarding their high estrogenic potential.

In Lisbon, Portugal, Rocha et al. (2015) collected water samples from nine sites in Tagus River during the four seasons of 2011. By using gas chromatography, 
the authors evaluated 17 EDsE, including natural, pharmaceutical, industrial and domestic pollutants, phytoestrogens and phytosterols. The estrogens derived from industrial/domestic activities were found in two of the nine sampled sites (both in Lisbon region). The toxicological values obtained from E-screen assays (expressed as ethinylestradiol equivalent (ng/L)) showed an estrogenic index of $13 \mathrm{ng} / \mathrm{L}$ for estrogens, $2.3 \mathrm{ng} / \mathrm{L}$ for domestic/industrial pollutants, and $43 \mathrm{ng} / \mathrm{L}$ for phytoestrogens. From the obtained results, the authors assigned the toxicological significance, especially regarding the ecological importance of the studied sites. These data was supported by the physical chemical analysis, enabling the authors to conclude that the presence of EDs in these samples was due to anthropogenic action, resulting from domestic and industrial discharges and the presence of drugs.

Praveena et al. (2016) investigated the occurrence of estrogenic activity in surface waters and in sediment from Langat River (Selangor, Malaysia). The presence of steroid estrogens, such as E1, 17 $\beta$-E2, and E3 was verified, along with the synthetic estrogen $17 \alpha$ EE2. The results indicated the continuous disposal of estrogens from sewage and agricultural activity residues. However, the concentrations showed a low risk to aquatic organisms. Even so, the authors suggested that it would be interesting to verify the presence of other pollutants with endocrine disruptor potential such as the presence of alkyl phenolic components.

Wang et al. (2016) assessed the incidence, sources of phenolic contaminants and the endocrine disruptor bioaccumulation potential in Panlong River, China. The phenolic EDsE (ethoxylate (NP2EO), nonylphenolmono-ethoxylate (NP1EO), 4NP, BPA, 4-cumylphenol (4-CP), and 4-t-OP) are strongly present in this river with greatly increased residual levels in water and sediment from certain areas. The concentrations of 4-NP, BAP, 4CP, 4-t-OP, and the total phenolic EDsE levels in three prevailing fish species (Carassius auratus, Cyprinus carpio, and Anabarilius alburnops) were 63, $114,12,14$, and $201 \mathrm{ng} / \mathrm{g}$, respectively. The characteristics of the distribution of phenolic EDsE in water were similar to those found in the sediment; however, in fish, the distribution was different. The incidence, bioaccumulation, and sources of phenolic EDsE in fish were directly related to the distribution characteristics of industrial, residential, and agricultural areas on the Panlong River basin. The concentration of phenolic EDsE in urban areas was especially high compared to suburban areas, so the authors concluded that an imminent risk of estrogenicity to aquatic organisms and even to humans already exists in urban areas of the river.

Wu et al. (2016) performed a study to determine the concentrations of BPA, NP, OP, BP, and ND in bile extract of fish collected from Xin'an River as well as those obtained from Shanghai market, China. The concentrations of EDsE on the commercially acquired fish were higher, with high detection rates compared to fish collected from the river. The average concentrations of BPA, NP, OP, BP, and ND in country fish were 30.1, 203, 4.69, 7.84, and $0.514 \mu \mathrm{g} / \mathrm{L}$, respectively, and in commercial fish were $240,528,76.5,12.8$, and $5.26 \mu \mathrm{g} / \mathrm{L}$, respectively. The total average estrogenic activity of the river water was $3.32 \mathrm{ng} / \mathrm{L}$ estradiol equivalent. Moreover, the authors analyzed the BCFs (bioconcentration factors) in fish bile after 30 days of exposure to environmentally relevant concentrations of BPA in a research lab. The general data suggest that the analysis of fish bile can be an efficient method for monitoring the conditions of aquatic biota. According to Krishnan et al. (1993), the affinity of BPA to bind to estrogen receptors is weaker than the affinity of natural estrogen, but still has this binding ability (Kwon et al. 2000). Besides the presence of estrogenic compounds, some lakes from subtropical regions in China also present APs in sediments (Wu et al. 2006).

Compounds like NP, OP, E1, E2, and BPA were also found in Tama River, Tokyo. This river receives effluents from WWTPs which predominantly treat compounds from domestic origins. The detected concentrations of NP (51.6 to $147 \mathrm{ng} / \mathrm{L}$ ) and OP (6.9 to $81.9 \mathrm{ng} / \mathrm{L}$ ) were insufficient to induce estrogenicity in the MVLN cells, but the E1 (6.4 to $85.6 \mathrm{ng} / \mathrm{L}), \mathrm{E} 2(0.5$ to $12.3 \mathrm{ng} /$ $\mathrm{L}$ ), and BPA (4.8 to $76.3 \mathrm{ng} / \mathrm{L}$ ) concentrations were sufficient to induce estrogenic responses (Furuichi et al. 2004). However, Fenet et al. (2003) reported that the low AP concentrations in water samples do not exclude its estrogenic potential, as these compounds can bioaccumulate in aquatic organisms, even when in low concentrations in the environment.

Wang et al. (2012) analyzed, by YES assay, the estrogenicity of surface waters and sediments from 15 different sites of Yellow River, China. In general, the estrogenic compounds present in water and sediments from Yellow River showed low estrogenicity levels, which others authors characterized from medium to minimum estrogenic risks for most of the sites, with 
the exception of the site relating to the east of Lanshou, which presented high estrogenic levels.

Vega-López et al. (2007) evaluated, by in vitro tests performed with MCF-7 cells, water samples collected from Texcoco and Zumpango Mexican lakes, as these lakes received effluents from WWTPs and are the only place where the fish Girardinichthys viviparous is found. The authors noticed the estrogenicity in the water of these lakes and, by in vitro tests, the induction of vitellogenin in both sexes of G. viviparous fish descendants, when they reproduced in laboratory. The vitellogenin in studied males reached higher levels than the one produced by females.

The plasmatic vitellogenin increase in male fish is considered one of the most common biomarkers for the detection of estrogenic compounds in aquatic environments (Snyder et al. 2003). Strict related locals with the presence of species under threat of extinction deserve special attention with relation to the dumping of contaminants that may complicate the reproduction of them and, consequently, contribute to their extinction.

Song and Wang (2016) performed a study to investigate the estrogenic activities of four regions from Yellow River, by assays developed with the MVLN cell line. Besides establishing the EEQs of the samples, the VTG induction, GSI, and the hepatosomatic index (HSI) in adult males of the rice fishes (Oryzias latipes) exposed to the water collect from the river were verified. In another bioassay, a number of parameters were set: incubation time, hatchability, progeny survival, and VTG induction during a complete life cycle of the fish. The analyses confirmed the presence of endocrine disruptor chemicals in Yellow River. The authors warned that the fish collected from the Yiluohe and Qinhe sites are under reproductive risk and show compromised development. However, in the Xinmanghe site, no endocrine disruption risk was observed; this region may have other chemicals that are affecting the hatchability and survival of the fish.

Gagné et al. (2012) evaluated the estrogenicity of water extracts of a river and a lake under the influence of bituminous sands from Athabasca River, in primary culture of rainbow trout hepatocytes. The authors investigated the alterations caused on the estradiol receptors $\beta 2$ (ER) and VTG gene expressions. They observed that exposure to the water samples from the river and lake caused the highest expression of both genes, with VTG showing higher expression.
Garcia-Reyero et al. (2005) evaluated, using the RYA, the estrogenic activity of the extracts of sediment samples of 83 lakes from European mountains. Among the evaluated samples, 26 did not show any estrogenic potential (levels under $1 \mathrm{pg} / \mathrm{g}$ EEQ), while 13 showed high estrogenicity levels, reaching $350 \mathrm{ng} / \mathrm{g}$ EEQ. The chemical analysis performed by the authors revealed a strong correlation between estrogenic activity and the presence of contaminants of anthropogenic origin.

The analyses of sediments from Tokyo basin, next to locations which receive effluent dumping of WWTPs, revealed the presence of high levels of NP in samples (142 to $20,700 \mathrm{ng} / \mathrm{g}$ dry weight). Besides showing estrogenic activity, as determined by the bioassay with the double-hybrid system in yeast (Saccharomyces cerevisiae Y190 with human estrogen receptor $(\operatorname{Er} \alpha)$ and a coactivator (TIF2)), the NP was also the main factor responsible for more than $90 \%$ of the induction of plasmatic vitellogenin in male fish of the species Fundulua heteroclitus (Kurihara et al. 2007).

Bicchi et al. (2009) evaluated the influence of effluent discard in a river north of Italy, regarding the possible estrogenic activities of this receptor body. The authors associated chemical with biological analyses to monitor the estrogenicity of both urban WWTP effluent samples and surface water at the receptor river, before and after disposal. The main substances found in three different studied samples were BPA, DEP, DBP, DEHP, E1, and 4-t-BP. Regarding estrogenic activity, evaluated by E-screen assay, the values found were about 57 to $60 \%$ lower up- and downstream of the river, respectively, than the effluent samples. These findings suggest that the effluent did not contribute to a significant increase in estrogenicity of the hydric resource, perhaps due to the capacity of self-depuration and/or for the dilution of the effluent along the river course. However, the authors warned that, even with the low contribution of the effluent to the increasing estrogenicity in river waters, the estrogenic activity of these waters already indicates that the depuration process is insufficient to completely remove the EDsE, which can compromise its endemic biota.

The estrogenicity of effluents from two municipal WWTPs, as well as surface waters from the Rhine River in Worms City (Germany), collected after the disposal of these effluents, was evaluated by Pawlowski et al. (2004) in a study that used the YES assay. The estrogenic activity of the solidphase extracts was expressed in EEQ, and was about 
twice as high $(65.96 \pm 10.4 \mathrm{ng} / \mathrm{L})$ as the effluent from STP 1 than the effluent from STP $2(34.1 \pm 7.18 \mathrm{ng} /$ L) and about three to five times higher than the river water $(11.97 \pm 0.7 \mathrm{ng} / \mathrm{L}$ in the left riverside and $19.42 \pm 2.8 \mathrm{ng} / \mathrm{L}$ in the right riverside). As a result, the authors stated that, due to the high amount of steroid estrogens (especially E2 and EE2), as well as the high biological activity detected by the YES, the studied effluents can maximize the EDsE concentration in the water of this river, inducing estrogenic effects in the exposed aquatic organisms.

Schilirò et al. (2009) quantified the estrogenic activity of a WWTP effluent and water samples collected from September 2006 to May 2007, from a river in the northeast region in Italy which receives this effluent. The evaluation was performed with extracts of pre-concentrated samples and their respective dilutions, submitted to the E-screen assay. The cellular proliferation was dose-dependent and the $1: 10$ and $1: 100$ dilutions stimulated maximum proliferations. The test that was used was shown to be appropriate for determining the estrogenic activity of an environmental extract.

Raw waters with various degrees of pollution and after being treated were collected from four sites distributed in rivers in Sao Paulo state, Brazil. These waters were evaluated in terms of estrogenic activity by Bergamasco et al. (2011), using the Saccharomyces cerevisiae in vitro test BLYES (bioluminescent yeast estrogen assay). The highest rates of estrogenic activity were found at sites with higher pollution. Treated waters did not show estrogenic potentials or estrogenic compounds. The BLYES test showed high sensibility and good detection limits proving that this was an adequate tool to evaluate and monitor water samples.

\subsection{Techniques to Remove the EDs from Aquatic Environments}

New additional techniques, such as the oxidative and ozonation processes, have shown promising results for the removal of EDsE from water (Esplugas et al. 2007; Guedes Maniero et al. 2008). Reungoat et al. (2012) demonstrated, using the E-screen assay, that the use of ozonation by biological filtration with activated carbon in a WWTP in Australia enabled the removal of more than $95 \%$ of the estrogenic effluent. This study concluded that this type of treatment was sufficient to diminish the estrogens and xenoestrogens in the effluent and should be incorporated into the traditional treatment systems to ensure the preservation of water resources related to this type of effect. In addition, the authors stated that the incorporation of biological assays could complement the information provided by the chemical analyses, allowing a more satisfying evaluation of the efficiency of the treatment.

Dias et al. (2015) evaluated the estrogenicity in collected waters from Parnaiba do Sul and Guandu Brazilian Rivers by the YES assay. The samples were collected from the river close to WWTP disposal. In the water samples collected from the Guandu River, the efficiency of the removal of estrogenic activity was measured by ozonation and chlorination processes, after conventional water treatment (clarification and sand filtration), by investigating the estrogens and BPA peaks. The results indicated an alarming incidence of estrogenic activities at levels higher than $1 \mathrm{ng} / \mathrm{L}$ for some sites of the river. Another concern was the number of WWTP samples that exceeded $1 \mathrm{ng} / \mathrm{L}$ of EDsE. However, the oxidation methods (ozonation and chlorination) were efficient for the removal of estrogenic activities and the combination of both methods carried good results, using fewer oxidants.

Recently, Hamilton et al. (2016) explored the efficacy of a WWTP in Australia to remove the EDsE during the normal flow and effluent disposal peaks, using analyses of chemical traces for selected EDsE and in vitro bioassays to estrogenicity. The used bioassays were the estrogen receptor binding assay ERBA (determines estrogenic activity by measuring the amount of radiolabeled $17 \beta E 2$ bound to the ER), E-screen and yeast two-hybrid assay. During summer, the effluent volume increased to $68 \%$ and, consequently, also increased the nutrient concentration to at least $27 \%$. The hydraulic retention period was reduced by $40 \%$ compared to base flow data. Despite this pressure on the treatment system, the concentrations and the load of E1, $17 \beta-E 2, E 3, B P A, O P$, and NP were not significantly higher during the flow peak when compared to the base flow conditions. The chemical analyses and in vitro bioassays showed that the EDs removal efficacy of the WWTP was not affected by the different flow discharges, confirming that large flow variations are not capable of reducing the efficacy of EDsE removal from the STP.

These studies discussed in this section are compiled in Table 1. 


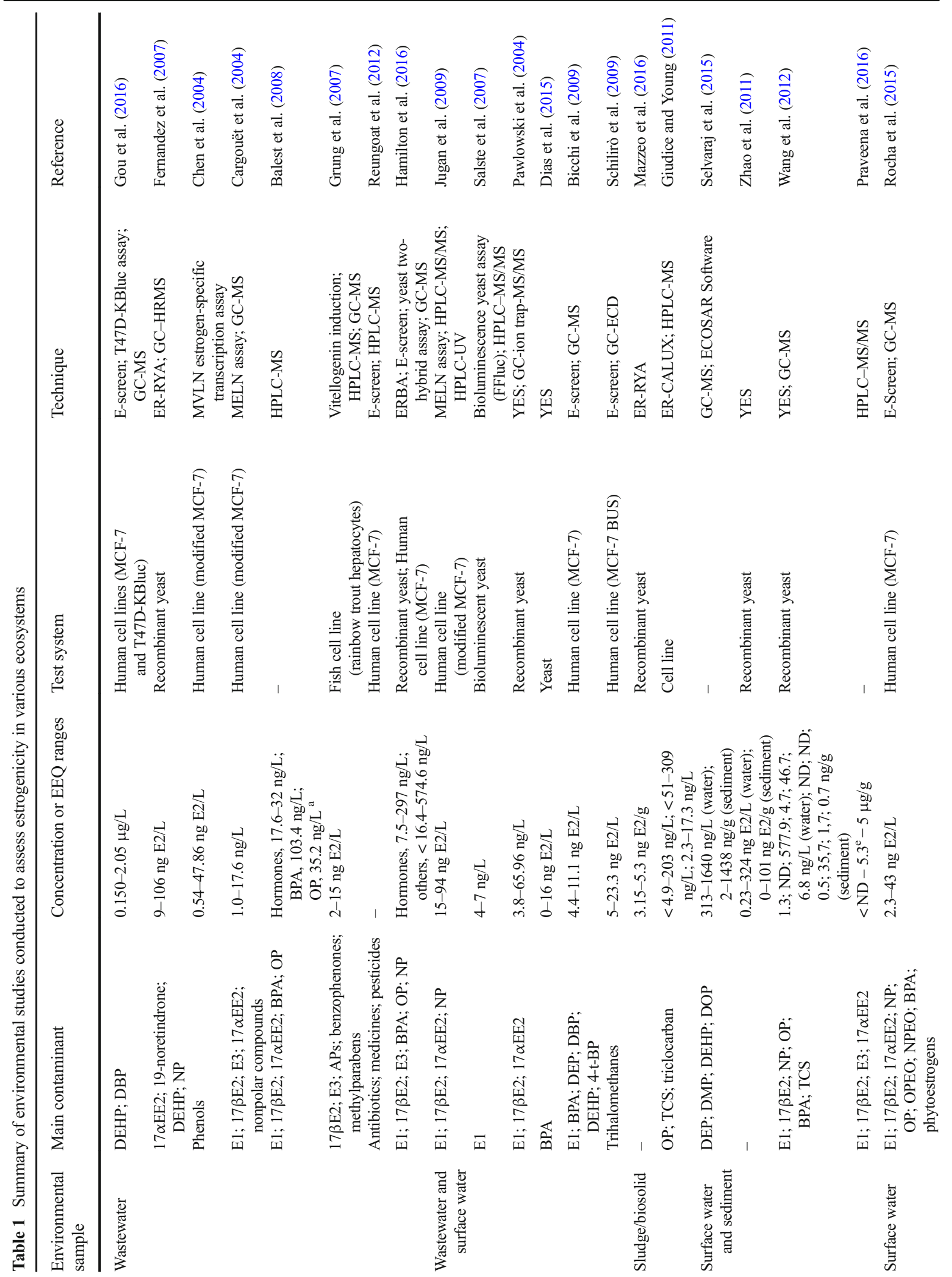




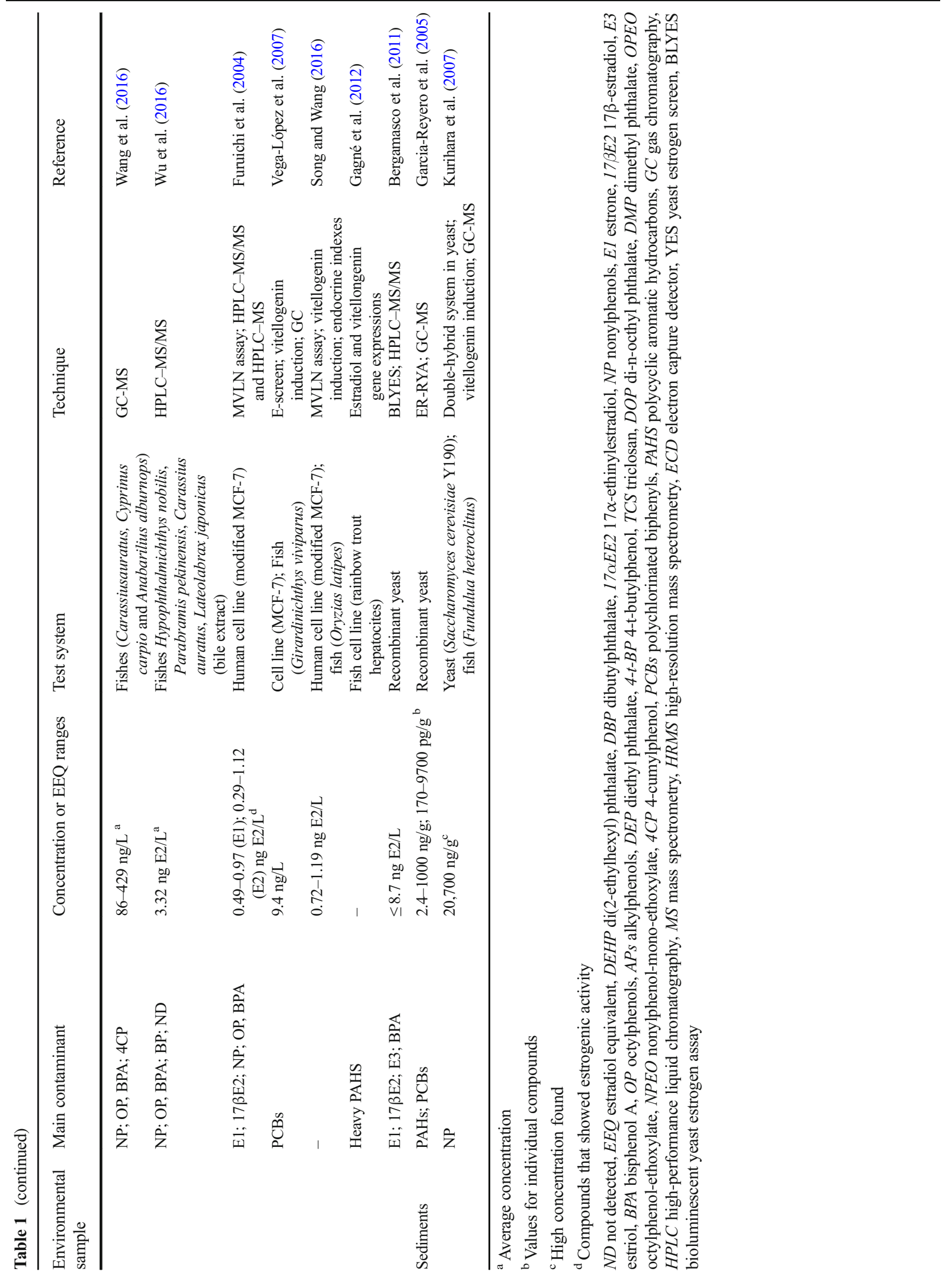




\section{Final Considerations}

Like many other substances that persist in the environment, the EDsE accumulate in soils, hydric resources, river sediments and along the food chain, representing, along with other pollutants, a serious risk to the health of organisms that are exposed to them. The EDsE cover a wide class of substances with distinct structures, including synthetic and natural hormones, natural substances and a great number of synthetic substances, with both organic and inorganic features that are also derived from residues or subproducts of many compounds used in industries, homes, and agriculture. Moreover, some current human activities can contribute to the dispersion of these contaminants, since many EDsE are present in plastic packages, in self-care products (such as soaps, shampoos, sunscreens and other), in contraceptives, in various medical/dental treatments, and in household cleaner products.

As discussed previously, the EDsE can react with the biological environment and negatively interfere with the endocrine system of organisms, in their most varied stages of development (from embryonic to adult). Thus, these emergent pollutants present a harmful potential over the exposed biota, including humans.

For this reason, many studies have been monitoring the presence of these substances in the environment. Due to the great variety of substances belong to the EDsE group and the wide variation in their concentrations in environmental samples, a combination of chemical and biological assays seems to be an interesting approach for the detection of these contaminants. As the EDsE are, in general, present in concentrations in the order of ng, high-performance chromatography is required to precisely quantify them. Among the bioassays, as highlighted by this review, methods using the human culture cell MCF-7 and recombinant yeast carrying the vertebrate estrogenic receptor are the most routinely employed. Additionally, studies that evaluate alterations in vitellogenin levels in fish, as an endpoint of estrogenicity, have also been frequently performed. However, despite all of the studies that have already been carried out to identify the presence of EDs in the most varied environmental matrices, the data are insufficient to elucidate the real action of these compounds on living beings (Bila and Dezotti 2007), especially due to the lack of knowledge regarding the existence of many compounds with estrogenic action.
Another important and critical issue to be considered is the need for data regarding the behavior of EDsE in the most diverse environmental matrices in relation to their persistence, accumulation, degradation, and mineralization. Furthermore, new technologies must be developed to improve the efficiency of wastewater treatments, since treated and untreated effluents represent the main source of introduction of EDsE to the environment. Therefore, due to their environmental relevance, this review reinforces the importance and necessity of studies related to the EDsE.

Acknowledgements This study was supported by the Fundação de Amparo à Pesquisa do Estado de São Paulo - FAPESP Processo 2011/16552-7 and Brazilian National Research Council - CNPq, Universal Project, Process no. 460962/2014-0.

\section{References}

Andersen, H. R., Andersson, A. M., Arnold, S. F., Autrup, H., Barfoed, M., Beresford, N. A., et al. (1999). Comparison of short-term estrogenicity tests for identification of hormonedisrupting chemicals. Environmental Health Perspectives, 107(Supp1), 89-108 http://www.ncbi.nlm.nih. gov/pubmed/10229711.

Andersen, H. R., Vinggaard, A. M., Rasmussen, T. H., Gjermandsen, I. M., \& Bonefeld-Jørgensen, E. C. (2002). Effects of currently used pesticides in assays for estrogenicity, androgenicity, and aromatase activity in vitro. Toxicology and Applied Pharmacology, 179(1), 1-12. https://doi.org/10.1006/taap.2001.9347.

Anderson, M. J., Cacela, D., Beltman, D., Teh, S. J., Okihiro, M. S., Hinton, D. E., et al. (2003). Biochemical and toxicopathic biomarkers assessed in smallmouth bass recovered from a polychlorinated biphenyl-contaminated river. Biomarkers, $8(5), 371-393$. https://doi.org/10.1080 $/ 13547500310001619293$.

Arukwe, A., \& Goksøyr, A. (2003). Eggshell and egg yolk proteins in fish: Hepatic proteins for the next generation: Oogenetic, population, and evolutionary implications of endocrine disruption. Comparative Hepatology, 2(1), 4. https://doi.org/10.1186/1476-5926-2-4.

Astiz, M., Acaz-Fonseca, E., \& Garcia-Segura, L. M. (2014). Sex differences and effects of estrogenic compounds on the expression of inflammatory molecules by astrocytes exposed to the insecticide dimethoate. Neurotoxicity Research, 25(3), 271-285. https://doi.org/10.1007/s12640-013-9417-0.

Baccarelli, A., Pesatori, A. C., \& Bertazzi, P. A. (2000). Occupational and environmental agents as endocrine disrupters: Experimental and human evidence. Journal of Endocrinological Investigation, 23(11), 771-781.

Baldigo, B. P., George, S. D., Phillips, P. J., Hemming, J. D. C., Denslow, N. D., \& Kroll, K. J. (2015). Potential estrogenic effects of wastewaters on gene expression in Pimephales 
promelas and fish assemblages in streams of southeastern New York. Environmental Toxicology and Chemistry, 34(12), 2803-2815. https://doi.org/10.1002/etc.3120.

Balest, L., Lopez, A., Mascolo, G., \& Di Iaconi, C. (2008). Removal of endocrine disrupter compounds from municipal wastewater using an aerobic granular biomass reactor. Biochemical Engineering Journal, 41(3), 288-294. https://doi.org/10.1016/j.bej.2008.05.015.

Barber, L. B., Loyo-Rosales, J. E., Rice, C. P., Minarik, T. A., \& Oskouie, A. K. (2015). Endocrine disrupting alkylphenolic chemicals and other contaminants in wastewater treatment plant effluents, urban streams, and fish in the Great Lakes and Upper Mississippi River Regions. Science of the Total Environment, 517, 195-206. https://doi.org/10.1016/j. scitotenv.2015.02.035.

Barouki, R. (2017). Endocrine disruptors: Revisiting concepts and dogma in toxicology. Comptes Rendus Biologies, 340(9-10), 410-413. https://doi.org/10.1016/j.crvi.2017.07.005.

Beausoleil, C., Ormsby, J.-N., Gies, A., Hass, U., Heindel, J. J., Holmer, M. L., et al. (2013). Low dose effects and nonmonotonic dose responses for endocrine active chemicals: Science to practice workshop: Workshop summary. Chemosphere, 93(6), 847-856. https://doi.org/10.1016/J. CHEMOSPHERE.2013.06.043.

Bennie, D. T., Sullivan, C. A., Lee, H.-B., Peart, T. E., \& Maguire, R. J. (1997). Occurrence of alkylphenols and alkylphenol mono- and diethoxylates in natural waters of the Laurentian Great Lakes basin and the upper St. Lawrence River. Science of the Total Environment, 193(3), 263-275. https://doi. org/10.1016/S0048-9697(96)05386-7.

Bergamasco, A. M. D. D., Eldridge, M., Sanseverino, J., Sodré, F. F., Montagner, C. C., Pescara, I. C., et al. (2011). Bioluminescent yeast estrogen assay (BLYES) as a sensitive tool to monitor surface and drinking water for estrogenicity. Journal of Environmental Monitoring : JEM, 13(11), 32883293. https://doi.org/10.1039/c1em10464k.

Bergeron, R. M., Thompson, T. B., Leonard, L. S., Pluta, L., \& Gaido, K. W. (1999). Estrogenicity of bisphenol A in a human endometrial carcinoma cell line. Molecular and Cellular Endocrinology, 150, 179-187 http://www.ncbi. nlm.nih.gov/pubmed/10411312.

Bernstein, B. E., Meissner, A., \& Lander, E. S. (2007). The mammalian epigenome. Cell, 128(4), 669-681. https://doi. org/10.1016/J.CELL.2007.01.033.

Bhatia, H., Kumar, A., Ogino, Y., Gregg, A., Chapman, J., McLaughlin, M. J., \& Iguchi, T. (2014). Di-n-butyl phthalate causes estrogenic effects in adult male Murray rainbowfish (Melanotaenia fluviatilis). Aquatic Toxicology, 149, 103-115. https://doi.org/10.1016/j.aquatox.2014.01.025.

Bhatt, R. V. (2000). Environmental influence on reproductive health, 69-75.

Bicchi, C., Schilirò, T., Pignata, C., Fea, E., Cordero, C., Canale, F., \& Gilli, G. (2009). Analysis of environmental endocrine disrupting chemicals using the E-screen method and stir bar sorptive extraction in wastewater treatment plant effluents. Science of the Total Environment, 407(6), 1842-1851. https://doi.org/10.1016/j.scitotenv.2008.11.039.

Bila, D. M., \& Dezotti, M. (2007). Desreguladores endócrinos no meio ambiente: Efeitos e conseqüências. Quimica Nova, 30(3), 651-666. https://doi.org/10.1590/S010040422007000300027.
Borman, S. M., Christian, P. J., Sipes, I. G., \& Hoyer, P. B. (2000). Ovotoxicity in female Fischer rats and B6 mice induced by low-dose exposure to three polycyclic aromatic hydrocarbons: Comparison through calculation of an ovotoxic index. Toxicology and Applied Pharmacology, 167(3), 191-198. https://doi.org/10.1006/TAAP.2000.9006.

Brzozowski, A. M., Pike, A. C., Dauter, Z., Hubbard, R. E., Bonn, T., Engström, O., et al. (1997). Molecular basis of agonism and antagonism in the oestrogen receptor. Nature, 389(6652), 753-758. https://doi.org/10.1038/39645.

Buckland, R. (2015). DNA precursor asymmetries, Mismatch Repair and their effect on mutation specificity,. Umeå University.

Campbell, C. G., Borglin, S. E., Green, F. B., Grayson, A., Wozei, E., \& Stringfellow, W. T. (2006). Biologically directed environmental monitoring, fate, and transport of estrogenic endocrine disrupting compounds in water: a review. Chemosphere, 65(8), 1265-1280. https://doi.org/10.1016/j. chemosphere.2006.08.003.

Cargouët, M., Perdiz, D., Mouatassim-Souali, A., TamisierKarolak, S., \& Levi, Y. (2004). Assessment of river contamination by estrogenic compounds in Paris area (France). Science of the Total Environment, 324(1-3), 55-66. https://doi.org/10.1016/j.scitotenv.2003.10.035.

Cavallin, J. E., Jensen, K. M., Kahl, M. D., Villeneuve, D. L., Lee, K. E., Schroeder, A. L., et al. (2016). Pathway-based approaches for assessment of real-time exposure to an estrogenic wastewater treatment plant effluent on fathead minnow reproduction. Environmental Toxicology and Chemistry, 35(3), 702-716. https://doi.org/10.1002/etc.3228.

Charles, G. D., Gennings, C., Zacharewski, T. R., Gollapudi, B. B., \& Carney, E. W. (2002). An approach for assessing estrogen receptor-mediated interactions in mixtures of three chemicals: a pilot study. Toxicological Sciences: an Official Journal of the Society of Toxicology, 68(2), 349-360. https://doi.org/10.1093/toxsci/68.2.349.

Chen, F. A., Shue, M. F., \& Chen, T. C. (2004). Evaluation on estrogenicity and oxidative hepatotoxicity of fossil fuel industrial wastewater before and after the powdered activated carbon treatment. Chemosphere, 55(10), 1377-1385. https://doi.org/10.1016/j.chemosphere.2003.11.058.

Chen, T. C., Shue, M. F., Yeh, Y. L., \& Kao, T. J. (2010). Bisphenol A occurred in Kao-Pin River and its tributaries in Taiwan. Environmental Monitoring and Assessment, 161(1-4), 135-145. https://doi.org/10.1007/s10661-0080733-4.

Chen, X., Xu, S., Tan, T., Lee, S. T., Cheng, S. H., Lee, F. W. F., et al. (2014). Toxicity and estrogenic endocrine disrupting activity of phthalates and their mixtures. International Journal of Environmental Research and Public Health, 11(3), 3156-3168. https://doi.org/10.3390/ijerph110303156.

Choe, S. Y., Kim, S. J., Kim, H. G., Lee, J. H., Choi, Y., Lee, H., \& Kim, Y. (2003). Evaluation of estrogenicity of major heavy metals. Science of the Total Environment, 312(1-3), 15-21. https://doi.org/10.1016/S0048-9697(03)00190-6.

Csaba, G., Karabélyos, C., \& Dalló, J. (1993). Fetal and neonatal action of a polycyclic hydrocarbon (benzpyrene) or a synthetic steroid hormone (allylestrenol) as reflected by the sexual behaviour of adult rats. Journal of Developmental Physiology, 19(2), 67-70 http://www.ncbi.nlm.nih. gov/pubmed/8409276. 
Darbre, P. D. (2001). Environmental contaminants in milk: The problem of organochlorine xenobiotics. Pre and PostPartum Nutrition and Metabolism, 26(1995), 37-43.

Darbre, P. D. (2015). What are endocrine disrupters and where are they found? In Endocrine disruption and human health (pp. 3-26). Elsevier. https://doi.org/10.1016/B978-0-12-8011393.00001-6.

Department of Health and Human Services. (2012). Fourth national report on human exposure to environmental chemicals. Centers for Disease Control and Prevention, 75-112. http://www.cdc.gov/exposurereport/pdf/fourthreport.pdf

Diamanti-Kandarakis, E., Palioura, E., Kandarakis, S. A., \& Koutsilieris, M. (2010). The impact of endocrine disruptors on endocrine targets. Hormone and Metabolic Research = Hormon- und Stoffwechselforschung $=$ Hormones et Metabolisme, 42(8), 543-552. https://doi.org/10.1055/s0030-1252034.

Dias, A. C. V., Gomes, F. W., Bila, D. M., Sant'Anna, G. L., \& Dezotti, M. (2015). Analysis of estrogenic activity in environmental waters in Rio de Janeiro state (Brazil) using the yeast estrogen screen. Ecotoxicology and Environmental Safety, 120, 41-47. https://doi.org/10.1016/j. ecoenv.2015.05.013

Díaz-Cruz, M. S., López de Alda, M. J., López, R., \& Barceló, D. (2003). Determination of estrogens and progestogens by mass spectrometric techniques (GC/MS, LC/MS and LC/ MS/MS). Journal of Mass Spectrometry, 38(9), 917-923. https://doi.org/10.1002/jms.529.

Drummond, A. E., \& Fuller, P. J. (2010). The importance of ERbeta signalling in the ovary. The Journal of Endocrinology, 205(1), 15-23. https://doi.org/10.1677/JOE09-0379.

Erickson, B. E. (2002). Analyzing the ignored environmental contaminants. Environmental Science \& Technology, 36(7), $140 \mathrm{~A}-145 \mathrm{~A}$ http://www.ncbi.nlm.nih. gov/pubmed/11999044.

Esplugas, S., Bila, D. M., Krause, L. G. T., \& Dezotti, M. (2007). Ozonation and advanced oxidation technologies to remove endocrine disrupting chemicals (EDCs) and pharmaceuticals and personal care products (PPCPs) in water effluents. Journal of Hazardous Materials, 149(3), 631-642. https://doi.org/10.1016/j.jhazmat.2007.07.073.

Esteller, M. (2007). Cancer epigenomics: DNA methylomes and histone-modification maps. Nature Reviews. Genetics, 8(4), 286-298. https://doi.org/10.1038/nrg2005.

Fenet, H., Gomez, E., Pillon, A., Rosain, D., Nicolas, J. C., Casellas, C., \& Balaguer, P. (2003). Estrogenic activity in water and sediments of a French river: Contribution of alkylphenols. Archives of Environmental Contamination and Toxicology, 44(1), 1-6. https://doi.org/10.1007/s00244002-1198-z.

Fernandez, M. P., Ikonomou, M. G., \& Buchanan, I. (2007). An assessment of estrogenic organic contaminants in Canadian wastewaters. Science of the Total Environment, 373(1), 250269. https://doi.org/10.1016/j.scitotenv.2006.11.018.

Finkelman, R. B., Belkin, H. E., \& Zheng, B. (1999). Health impacts of domestic coal use in China. Proceedings of the National Academy of Sciences of the United States of America, 96(March), 3427-3431. https://doi.org/10.1073 /pnas.96.7.3427.
Folmar, L. C., Hemmer, M. J., Denslow, N. D., Kroll, K., Chen, J., Cheek, A., et al. (2002). A comparison of the estrogenic potencies of estradiol, ethynylestradiol, diethylstilbestrol, nonylphenol and methoxychlor in vivo and in vitro. Aquatic Toxicology, 60(1-2), 101-110. https://doi. org/10.1016/S0166-445X(01)00276-4.

Fontenele, E. G. P., Martins, M. R. A., Quidute, A. R. P., \& Montenegro Júnior, R. M. (2010). Contaminantes ambientais e os interferentes endócrinos. Arquivos Brasileiros de Endocrinologia \& Metabologia, 54(1), 6-16. https://doi. org/10.1590/S0004-27302010000100003.

Foster, P. M. D. (2006). Disruption of reproductive development in male rat offspring following in utero exposure to phthalate esters. International Journal of Andrology, 29(1), 140-147. https://doi.org/10.1111/j.1365-2605.2005.00563.x.

Furuichi, T., Kannan, K., Giesy, J. P., \& Masunaga, S. (2004). Contribution of known endocrine disrupting substances to the estrogenic activity in Tama River water samples from Japan using instrumental analysis and in vitro reporter gene assay. Water Research, 38(20), 4491-4501. https://doi. org/10.1016/j.watres.2004.08.007.

Gagné, F., Douville, M., André, C., Debenest, T., Talbot, A., Sherry, J., et al. (2012). Differential changes in gene expression in rainbow trout hepatocytes exposed to extracts of oil sands process-affected water and the Athabasca River. Comparative Biochemistry and Physiology - C Toxicology and Pharmacology, 155(4), 551-559. https://doi.org/10.1016 j.cbpc.2012.01.004.

Garcia-Reyero, N., Piña, B., Grimalt, J. O., Fernández, P., Fonts, R., Polvillo, O., \& Martrat, B. (2005). Estrogenic activity in sediments from European mountain lakes. Environmental Science and Technology, 39(6), 1427-1435. https://doi. org/10.1021/es0400685.

Ghiselli, G., \& Jardim, W. F. (2007). Interferentes endócrinos no meio ambiente. Quimica Nova, 30(3), 695-706. https://doi. org/10.1590/S0100-40422007000300032.

Gilman, A., Hardman, J., \& Limbird, L. (2003). As bases farmacológicas da terapêtica. (10th ed.). Rio de Janeiro.

Gioiosa, L., Palanza, P., Parmigiani, S., \& Vom Saal, F. S. (2015). Risk evaluation of endocrine-disrupting chemicals: effects of developmental exposure to low doses of bisphenol a on behavior and physiology in mice (Mus musculus). DoseResponse, 13(4), 1-8. https://doi.org/10.1177 $/ 1559325815610760$.

Giudice, B. D., \& Young, T. M. (2011). Mobilization of endocrinedisrupting chemicals and estrogenic activity in simulated rainfall runoff from land-applied biosolids. Environmental Toxicology and Chemistry, 30(10), 2220-2228. https://doi. org/10.1002/etc.631.

Gorga, M., Insa, S., Petrovic, M., \& Barceló, D. (2015). Occurrence and spatial distribution of EDCs and related compounds in waters and sediments of Iberian rivers. Science of the Total Environment, 503-504, 69-86. https://doi.org/10.1016/j.scitotenv.2014.06.037.

Gou, Y. Y., Lin, S., Que, D. E., Tayo, L. L., Lin, D. Y., Chen, K. C., et al. (2016). Estrogenic effects in the influents and effluents of the drinking water treatment plants. Environmental Science and Pollution Research, 23(9), 8518-8528. https://doi.org/10.1007/s11356-015-5946-9.

Grung, M., Lichtenthaler, R., Ahel, M., Tollefsen, K. E., Langford, K., \& Thomas, K. V. (2007). Effects-directed analysis of 
organic toxicants in wastewater effluent from Zagreb, Croatia. Chemosphere, 67(1), 108-120. https://doi. org/10.1016/j.chemosphere.2006.09.021.

Guedes Maniero, M., Maia Bila, D., \& Dezotti, M. (2008). Degradation and estrogenic activity removal of $17 \beta$ estradiol and $17 \alpha$-ethinylestradiol by ozonation and $\mathrm{O} 3 /$ H2O2. Science of the Total Environment, 407(1), 105-115. https://doi.org/10.1016/j.scitotenv.2008.08.011.

Halling-Sorensen, B., Halling-Sorensen, B., Nielsen, S. N., Nielsen, S. N., Lanzky, P. F., Lanzky, P. F., et al. (1998). Occurrence, fate and effects of pharmaceuticals substance in the environment — a review. Chemosphere, 36(2), 357-393. https://doi.org/10.1016/S0045-6535(97)00354-8.

Hamilton, L. A., Tremblay, L. A., Northcott, G. L., Boake, M., \& Lim, R. P. (2016). The impact of variations of influent loading on the efficacy of an advanced tertiary sewage treatment plant to remove endocrine disrupting chemicals. Science of the Total Environment, 560-561, 101-109. https://doi. org/10.1016/j.scitotenv.2016.04.003.

Harvey, P. W., \& Johnson, I. (2002). Approaches to the assessment of toxicity data with endpoints related to endocrine disruption. Journal of Applied Toxicology, 22(4), 241-247. https://doi.org/10.1002/jat.854.

Hashimoto, S., Bessho, H., Hara, A., Nakamura, M., Iguchi, T., \& Fujita, K. (2000). Elevated serum vitellogenin levels and gonadal abnormalities in wild male flounder (Pleuronectes yokohamae) from Tokyo Bay, Japan. Marine Environmental Research, 49(1), 37-53. https://doi.org/10.1016/S0141-1136 (99)00047-1.

Hemming, J. M., Allen, H. J., Thuesen, K. A., Turner, P. K., Waller, W. T., Lazorchak, J. M., et al. (2004). Temporal and spatial variability in the estrogenicity of a municipal wastewater effluent. Ecotoxicology and Environmental Safety, 57(3), 303-310. https://doi.org/10.1016/S0147-6513(03 00025-3.

Hilscherova, K., Machala, M., Kannan, K., Blankenship, A. L., \& Giesy, J. P. (2000). Cell bioassays for detection of aryl hydrocarbon $(\mathrm{AhR})$ and estrogen receptor (ER) mediated activity in environmental samples. Environmental Science and Pollution Research International, 7(3), 159-171. https://doi.org/10.1065/espr2000.02.017.

Hinck, J. E., Blazer, V. S., Denslow, N. D., Echols, K. R., Gross, T. S., May, T. W., et al. (2007). Chemical contaminants, health indicators, and reproductive biomarker responses in fish from the Colorado River and its tributaries. Science of the Total Environment, 378(3), 376-402. https://doi.org/10.1016/j. scitotenv.2007.02.032.

Hseu, Z. Y. (2006). Response of microbial activities in two contrasting soils to 4-nonylphenol treated with biosolids. Chemosphere, 64(10), 1769-1776. https://doi.org/10.1016/j. chemosphere.2005.12.042.

Hsieh, T.-H., Tsai, C.-F., Hsu, C.-Y., Kuo, P.-L., Hsi, E., Suen, J.L., et al. (2012a). N-butyl benzyl phthalate promotes breast cancer progression by inducing expression of lymphoid enhancer factor 1. PLoS ONE, 7(8), e42750. https://doi. org/10.1371/journal.pone.0042750.

Hsieh, T.-H., Tsai, C.-F., Hsu, C.-Y., Kuo, P.-L., Lee, J.-N., Chai, C.-Y., et al. (2012b). Phthalates induce proliferation and invasiveness of estrogen receptor-negative breast cancer through the AhR/HDAC6/c-Myc signaling pathway. FASEB Journal: Official Publication of the Federation of American
Societies for Experimental Biology, 26(2), 778-787. https://doi.org/10.1096/fj.11-191742.

Hsu, P.-Y., Deatherage, D. E., Rodriguez, B. A. T., Liyanarachchi, S., Weng, Y.-I., Zuo, T., et al. (2009). Xenoestrogen-induced epigenetic repression of microRNA-9-3 in breast epithelial cells. Cancer Research, 69(14), 5936-5945. https://doi. org/10.1158/0008-5472.CAN-08-4914.

Jacobs, M. (2001). Unsafe sex: How endocrine disruptors work. In M. Jacobs \& B. Dinham (Eds.), Pesticides, livelihoods and women's health (Vol. 4, p. 14). Zed.

Janošek, J., Hilscherová, K., Bláha, L., \& Holoubek, I. (2006). Environmental xenobiotics and nuclear receptorsInteractions, effects and in vitro assessment. Toxicology In Vitro, 20(1), 18-37. https://doi.org/10.1016/j. tiv.2005.06.001.

Jefferson, W. N., Padilla-Banks, E., \& Newbold, R. R. (2005). Adverse effects on female development and reproduction in CD-1 mice following neonatal exposure to the phytoestrogen genistein at environmentally relevant doses. Biology of Reproduction, 73(4), 798-806. https://doi.org/10.1095 /biolreprod.105.041277.

Jirtle, R. L., \& Skinner, M. K. (2007). Environmental epigenomics and disease susceptibility. Nature Reviews Genetics, 8(4), 253-262. https://doi.org/10.1038/nrg2045.

Jobling, S., Nolan, M., Tyler, C. R., Brighty, G., \& Sumpter, J. P. (1998). Widespread sexual disruption in wild fish. Environmental Science \& Technology, 32(17), 2498-2506. https://doi.org/10.1021/es9710870.

Jobling, S., Coey, S., Whitmore, J. G., Kime, D. E., Van Look, K. J. W., McAllister, B. G., et al. (2002). Wild intersex roach (Rutilus rutilus) have reduced fertility. Biology of Reproduction, 67(2), 515-524 http://www.ncbi.nlm.nih. gov/pubmed/12135890.

Jones, P., De Coen, W., Tremblay, T., \& Giesy, J. (2000). Vitellogenin as a biomarker for environmental estrogens. Water Science and Technology, 42(7-8), 1-14.

Jugan, M. L., Oziol, L., Bimbot, M., Huteau, V., Tamisier-Karolak, S., Blondeau, J. P., \& Lévi, Y. (2009). In vitro assessment of thyroid and estrogenic endocrine disruptors in wastewater treatment plants, rivers and drinking water supplies in the greater Paris area (France). The Science of the Total Environment, 407(11), 3579-3587. https://doi.org/10.1016 j.scitotenv.2009.01.027.

Kang, S. C., \& Lee, B. M. (2005). DNA methylation of estrogen receptor alpha gene by phthalates. Journal of Toxicology and Environmental Health. Part A, 68(23-24), 1995-2003. https://doi.org/10.1080/15287390491008913.

Kavouras, I. G., Koutrakis, P., Tsapakis, M., Lagoudaki, E., Stephanou, E. G., Von Baer, D., \& Oyola, P. (2001). Source apportionment of urban particulate aliphatic and polynuclear aromatic hydrocarbons (PAHs) using multivariate methods. Environmental Science \& Technology, 35(11), 2288-2294 http://www.ncbi.nlm.nih.gov/pubmed/11414034.

Kawahata, H., Ohta, H., Inoue, M., \& Suzuki, A. (2004). Endocrine disrupter nonylphenol and bisphenol A contamination in Okinawa and Ishigaki Islands, Japan — within coral reefs and adjacent river mouths. Chemosphere, 55(11), 1519-1527. https://doi.org/10.1016/j.chemosphere.2004.01.032.

Kelley, K. E., Hernández-Díaz, S., Chaplin, E. L., Hauser, R., \& Mitchell, A. A. (2012). Identification of phthalates in medications and dietary supplement formulations in the United 
States and Canada. Environmental Health Perspectives, 120(3), 379-384. https://doi.org/10.1289/ehp.1103998.

Kelly, A., Hatcher, M. J., \& Dunn, A. M. (2004). Intersexuality in the amphipod Gammarus duebeni results from incomplete feminisation by the vertically transmitted parasitic sex ratio distorter Nosema granulosis. Evolutionary Ecology, 18(2), 121-132. https://doi.org/10.1023/B:EVEC.0000021091.27606.3c.

Kime, D., Nash, J., \& Scott, A. (1999). Vitellogenesis as a biomarker of reproductive disruption by xenobiotics. Aquaculture, 177(1-4), 345-352. https://doi.org/10.1016 /S0044-8486(99)00097-6.

Kinch, C. D., Ibhazehiebo, K., Jeong, J.-H., Habibi, H. R., \& Kurrasch, D. M. (2015). Low-dose exposure to bisphenol A and replacement bisphenol $\mathrm{S}$ induces precocious hypothalamic neurogenesis in embryonic zebrafish. Proceedings of the National Academy of Sciences, 112(5), 1475-1480. https://doi.org/10.1073/pnas.1417731112.

Kiyama, R., \& Wada-Kiyama, Y. (2015). Estrogenic endocrine disruptors: molecular mechanisms of action. Environment International, 83, 11-40. https://doi.org/10.1016/j. envint.2015.05.012.

Knower, K. C., Tor, S. Q., Leung, Y.-K., Ho, S.-M., \& Clyne, C. D. (2014). Endocrine disruption of the epigenome: a breast cancer link. Endocrine-Related Cancer, 21(2), T33-T55. https://doi.org/10.1530/ERC-13-0513.

Kojima, H., Katsura, E., Takeuchi, S., Niiyama, K., \& Kobayashi, K. (2004). Screening for estrogen and androgen receptor activities in 200 pesticides by in vitro reporter gene assays using Chinese hamster ovary cells. Environmental Health Perspectives, 112(5), 524-531. https://doi.org/10.1289 /ehp.6649.

Kolpin, D. W., Furlong, E. T., Meyer, M. T., Thurman, E. M., Zaugg, S. D., Barber, L. B., \& Buxton, H. T. (2002). Pharmaceuticals, hormones, and other organic wastewater contaminants in U.S. streams, 1999-2000: a national reconnaissance. Environmental Science \& Technology, 36(6), 1202-1211 http://www.ncbi.nlm. nih.gov/pubmed/11944670.

Kortenkamp, A. (2007). Ten years of mixing cocktails: a review of combination effects of endocrine-disrupting chemicals. Environmental Health Perspectives, 115((SUPPL1)), 98105. https://doi.org/10.1289/ehp.9357.

Krishnan, A. V., Stathis, P., Permuth, S. F., Tokes, L., \& Feldman, D. (1993). Bisphenol-A: an estrogenic substance is released from polycarbonate flasks during autoclaving. Endocrinology, 132(6), 2279-2286. https://doi.org/10.1210 lendo.132.6.8504731.

Kurihara, R., Watanabe, E., Ueda, Y., Kakuno, A., Fujii, K., Shiraishi, F., \& Hashimoto, S. (2007). Estrogenic activity in sediments contaminated by nonylphenol in Tokyo Bay (Japan) evaluated by vitellogenin induction in male mummichogs (Fundulus heteroclitus). Marine Pollution Bulletin, 54(9), 1315-1320. https://doi.org/10.1016/j. marpolbul.2007.06.007.

Kwon, S., Stedman, D. B., Elswick, B. A., Cattley, R. C., \& Welsch, F. (2000). Pubertal development and reproductive functions of Crl:CD BR Sprague-Dawley rats exposed to bisphenol A during prenatal and postnatal development. Toxicological Sciences: an Official Journal of the Society of Toxicology, 55(2), 399-406 http://www.ncbi.nlm.nih. gov/pubmed/10828273.
Lafuente, A., \& Pereiro, N. (2013). Neurotoxic effects induced by endosulfan exposure during pregnancy and lactation in female and male rat striatum. Toxicology, 311(1-2), 35-40. https://doi.org/10.1016/J.TOX.2013.05.001.

Lagarde, F., Beausoleil, C., Belcher, S. M., Belzunces, L. P., Emond, C., Guerbet, M., \& Rousselle, C. (2015). Nonmonotonic dose-response relationships and endocrine disruptors: a qualitative method of assessment. Environmental Health: a Global Access Science Source, 14(1), 13. https://doi.org/10.1186/1476-069X-14-13.

Lavado, R., Thibaut, R., Raldúa, D., Martín, R., \& Porte, C. (2004). First evidence of endocrine disruption in feral carp from the Ebro River. Toxicology and Applied Pharmacology, 196(2), 247-257. https://doi.org/10.1016/j.taap.2003.12.012.

Lejonklou, M. H., Dunder, L., Bladin, E., Pettersson, V., Rönn, M., Lind, L., et al. (2017). Effects of low-dose developmental bisphenol A exposure on metabolic parameters and gene expression in male and female fischer 344 rat offspring. Environmental Health Perspectives, 125(6), 1-13. https://doi.org/10.1289/EHP505.

Lester, J., \& Edge, D. (2001). Sewage and sewage sludge treatment. In Pollution: Causes, effects and control (pp. 113144). Cambridge.

Letcher, R. J., Sanderson, J. T., Bokkers, A., Giesy, J. P., \& van den Berg, M. (2005). Effects of bisphenol A-related diphenylalkanes on vitellogenin production in male carp (Cyprinus carpio) hepatocytes and aromatase (CYP19) activity in human H295R adrenocortical carcinoma cells. Toxicology and Applied Pharmacology, 209(2), 95-104. https://doi.org/10.1016/j.taap.2005.03.013.

Levy, G., Lutz, I., Krüger, A., \& Kloas, W. (2004). Bisphenol A induces feminization in Xenopus laevis tadpoles. Environmental Research, 94(1), 102-111 http://www.ncbi. nlm.nih.gov/pubmed/14643292.

Lezcano, V., Fernández, C., Parodi, E., \& Morelli, S. (2017). Comparative study of the action of phytoestrogens and algae extract in tumoral cells. Bone, 105, 301-302. https://doi. org/10.1016/J.BONE.2017.03.020.

Li, X.-M., Luo, F.-N., Liu, G.-X., \& Zhu, P.-T. (2008). Bioassay of estrogenic activity of effluent and influent in a farm wastewater treatment plant using an in vitro recombinant assay with yeast cells. Biomedical and Environmental Sciences: BES, 21(5), 381-388. https://doi.org/10.1016/S0895-3988 (08)60058-6.

Liney, K. E., Hagger, J. A., Tyler, C. R., Depledge, M. H., Galloway, T. S., \& Jobling, S. (2006). Health effects in fish of long-term exposure to effluents from wastewater treatment works. Environmental Health Perspectives, 114(Suppl), 8189 http://www.ncbi.nlm.nih.gov/pubmed/16818251.

Lintelmann, J., Katayama, A., Kurihara, N., Shore, L., \& Wenzel, A. A. (2003). Endocrine disruptors in the environment (IUPAC technical report) endocrine disruptors in the environment. Pure and Applied Chemistry Schejbal (Czech Republic), 75(5), 631-681. https://doi.org/10.1351 /pac200375050631.

Liu, B., Zhou, S., Yang, C., Chen, P., Chen, P., Xi, D., et al. (2017). Bisphenol A deteriorates egg quality through HDAC7 suppression. Oncotarget, 8(54), 92359-92365. https://doi. org/10.18632/oncotarget.21308.

Ma, M., Rao, K., \& Wang, Z. (2007). Occurrence of estrogenic effects in sewage and industrial wastewaters in Beijing, China. 
Environmental Pollution (Barking, Essex: 1987), 147(2), 331336. https://doi.org/10.1016/j.envpol.2006.05.032.

MacKenzie, K. M., \& Angevine, D. M. (1981). Infertility in mice exposed in utero to benzo(a)pyrene. Biology of Reproduction, 24(1), 183-191 http://www.ncbi.nlm.nih. gov/pubmed/7470542.

Mandich, A., Bottero, S., Benfenati, E., Cevasco, A., Erratico, C., Maggioni, S., et al. (2007). In vivo exposure of carp to graded concentrations of bisphenol a. General and Comparative Endocrinology, 153(1-3), 15-24. https://doi.org/10.1016/j. ygcen.2007.01.004.

Manikkam, M., Tracey, R., Guerrero-Bosagna, C., \& Skinner, M. K. (2013). Plastics derived endocrine disruptors (BPA, DEHP and DBP) induce epigenetic transgenerational inheritance of obesity, reproductive disease and sperm Epimutations. PLoS One, 8(1), e55387. https://doi. org/10.1371/journal.pone.0055387.

Martin-Skilton, R., Lavado, R., Thibaut, R., Minier, C., \& Porte, C. (2006). Evidence of endocrine alteration in the red mullet, Mullus barbatus from the NW Mediterranean. Environmental Pollution (Barking, Essex: 1987), 141(1), 60-68. https://doi. org/10.1016/j.envpol.2005.08.016.

Maurício, R., Diniz, M., Petrovic, M., Amaral, L., Peres, I., Barceló, D., \& Santana, F. (2006). A characterization of selected endocrine disruptor compounds in a Portuguese wastewater treatment plant. Environmental Monitoring and Assessment, 118(1-3), 75-87. https://doi.org/10.1007 /s10661-006-0986-8.

Mazzeo, D. E. C., Fernandes, T. C. C., \& Marin-Morales, M. A. (2016). Attesting the efficiency of monitored natural attenuation in the detoxification of sewage sludge by means of genotoxic and mutagenic bioassays. Chemosphere, 163, 508-515. https://doi.org/10.1016/j.chemosphere.2016.08.060.

Meeker, J. D., Sathyanarayana, S., \& Swan, S. H. (2009). Phthalates and other additives in plastics: human exposure and associated health outcomes. Philosophical transactions of the Royal Society of London. Series B, Biological sciences, 364(1526), 2097-2113. https://doi.org/10.1098 /rstb.2008.0268.

Melnick, R., Lucier, G., Wolfe, M., Hall, R., Stancel, G., Prins, G., et al. (2002). Summary of the National Toxicology Program's report of the endocrine disruptors low-dose peer review. Environmental Health Perspectives, 110(4), 427-431. https://doi.org/10.1289/ehp.02110427.

Meyer, A., Sarcinelli, P. N., \& Moreira, J. C. (1999). Estar?o alguns grupos populacionais brasileiros sujeitos ? a??o de disruptores end?crinos? Cadernos de Sa? de P?blica, 15(4), 845-850. https://doi.org/10.1590/S 0102-311 X1999000400018.

Milesi, M. M., Varayoud, J., Bosquiazzo, V. L., Muñoz-de-Toro, M., \& Luque, E. H. (2012). Neonatal exposure to low doses of endosulfan disrupts the expression of proteins regulating uterine development and differentiation. Reproductive Toxicology, 33(1), 85-93. https://doi.org/10.1016/J. REPROTOX.2011.12.003.

Milesi, M. M., Alarcón, R., Ramos, J. G., Muñoz-de-Toro, M., Luque, E. H., \& Varayoud, J. (2015). Neonatal exposure to low doses of endosulfan induces implantation failure and disrupts uterine functional differentiation at the preimplantation period in rats. Molecular and Cellular
Endocrinology, 401, 248-259. https://doi.org/10.1016/J. MCE.2014.11.028.

Milesi, M. M., Varayoud, J., Ramos, J. G., \& Luque, E. H. (2017). Uterine $E R \alpha$ epigenetic modifications are induced by the endocrine disruptor endosulfan in female rats with impaired fertility. Molecular and Cellular Endocrinology, 454, 1-11. https://doi.org/10.1016/j.mce.2017.05.028.

Mills, L. J., Gutjahr-Gobell, R. E., Haebler, R. A., Horowitz, D. J., Jayaraman, S., Pruell, R. J., et al. (2001). Effects of estrogenic (o,p'-DDT; octylphenol) and anti-androgenic (p,p'-DDE) chemicals on indicators of endocrine status in juvenile male summer flounder (Paralichthys dentatus). Aquatic toxicology (Amsterdam, Netherlands), 52(2), 157-176 http://www.ncbi. nlm.nih.gov/pubmed/11164537.

Mnif, W., Hassine, A. I. H., Bouaziz, A., Bartegi, A., Thomas, O., \& Roig, B. (2011). Effect of endocrine disruptor pesticides: a review. International Journal of Environmental Research and Public Health, 8(6), 2265-2303. https://doi. org/10.3390/ijerph8062265.

Moresco, R. M., Margarido, V. P., \& de Oliveira, C. (2014). A persistent organic pollutant related with unusual high frequency of hermaphroditism in the neotropical anuran Physalaemus cuvieri Fitzinger, 1826. Environmental Research, 132, 6-11. https://doi.org/10.1016/j. envres.2014.03.028.

Morissette, M., Morin, N., Rouillard, C., \& Di Paolo, T. (2018). Membrane cholesterol removal and replenishment affect rat and monkey brain monoamine transporters. Neuropharmacology, 133, 289-306. https://doi.org/10.1016 /J.NEUROPHARM.2018.01.039.

Mueller, S. O. (2004). Xenoestrogens: mechanisms of action and detection methods. Analytical and Bioanalytical Chemistry, 378(3), 582-587. https://doi.org/10.1007/s00216-003-2238$\mathrm{X}$.

Nadal, A., Fuentes, E., Ripoll, C., Villar-Pazos, S., CastellanoMuñoz, M., Soriano, S., et al. (2018). Extranuclear-initiated estrogenic actions of endocrine disrupting chemicals: Is there toxicology beyond paracelsus? The Journal of Steroid Biochemistry and Molecular Biology, 176, 16-22. https://doi.org/10.1016/J.JSBMB.2017.01.014.

Nakata, H., Uehara, K., Goto, Y., Fukumura, M., Shimasaki, H., Takikawa, K., \& Miyawaki, T. (2014). Polycyclic aromatic hydrocarbons in oysters and sediments from the Yatsushiro Sea, Japan: comparison of potential risks among PAHs, dioxins and dioxin-like compounds in benthic organisms. Ecotoxicology and Environmental Safety, 99, 61-68. https://doi.org/10.1016/j.ecoenv.2013.10.005.

Nesaretnam, K., \& Darbre, P. (1997). 3,5,3',5'-tetrachlorobiphenyl is a weak oestrogen agonist in vitro and in vivo. The Journal of Steroid Biochemistry and Molecular Biology, 62(5-6), 409-418 http://www.ncbi.nlm.nih.gov/pubmed/9449244.

Niemuth, N. J., \& Klaper, R. D. (2015). Emerging wastewater contaminant metformin causes intersex and reduced fecundity in fish. Chemosphere, 135, 38-45. https://doi.org/10.1016 /j.chemosphere.2015.03.060.

Okoumassoun, L.-E., Brochu, C., Deblois, C., Akponan, S., Marion, M., Averill-Bates, D., \& Denizeau, F. (2002). Vitellogenin in tilapia male fishes exposed to organochlorine pesticides in Ouémé River in Republic of Benin. The Science of the Total Environment, 299(1-3), 163-172 http://www. ncbi.nlm.nih.gov/pubmed/12462582. 
Oliveira, D. P., Carneiro, P. A., Sakagami, M. K., Zanoni, M. V. B., \& Umbuzeiro, G. A. (2007). Chemical characterization of a dye processing plant effluent-identification of the mutagenic components. Mutation Research, 626(1-2), 135-142. https://doi.org/10.1016/j.mrgentox.2006.09.008.

Osman, A., Alsomait, H., Seshadri, S., El-Toukhy, T., \& Khalaf, Y. (2015). The effect of sperm DNA fragmentation on live birth rate after IVF or ICSI: a systematic review and meta-analysis. Reproductive Biomedicine Online, 30(2), 120-127. https://doi.org/10.1016/j.rbmo.2014.10.018.

Patel, S., Hartman, J. A., Helferich, W. G., \& Flaws, J. A. (2017). Preconception exposure to dietary levels of genistein affects female reproductive outcomes. Reproductive Toxicology, 74, $174-180$. https://doi.org/10.1016/J . REPROTOX.2017.09.014.

Patisaul, H. (2009). Long-term effects of environmental endocrine disruptors on reproductive physiology and behavior. Frontiers in Behavioral Neuroscience, 3(June), 1-18. https://doi.org/10.3389/neuro.08.010.2009.

Pawlowski, S., Ternes, T. A., Bonerz, M., Rastall, A. C., Erdinger, L., \& Braunbeck, T. (2004). Estrogenicity of solid phaseextracted water samples from two municipal sewage treatment plant effluents and river Rhine water using the yeast estrogen screen. Toxicology In Vitro: an International Journal Published in Association with BIBRA, 18(1), 129138 http://www.ncbi.nlm.nih.gov/pubmed/14630071.

Payne, J., Rajapakse, N., Wilkins, M., \& Kortenkamp, A. (2000). Prediction and assessment of the effects of mixtures of four xenoestrogens. Environmental Health Perspectives, 108(10), 983-987. https://doi.org/10.1289/ehp.00108983.

Payne, J., Scholze, M., \& Kortenkamp, A. (2001). Mixtures of four organochlorines enhance human breast cancer cell proliferation. 109(4), 391-397.

Petrovic, M., Diaz, A., Ventura, F., \& Barceló, D. (2001). Simultaneous determination of halogenated derivatives of alkylphenol ethoxylates and their metabolites in sludges, river sediments, and surface, drinking, and wastewaters by liquid chromatography-mass spectrometry. Analytical Chemistry, 73(24), 5886-5895. https://doi.org/10.1021 /ac010677k.

Pickford, D. B., Jones, A., Velez-Pelez, A., Orton, F., Iguchi, T., Mitsui, N., \& Tooi, O. (2015). Screening breeding sites of the common toad (Bufo bufo) in England and Wales for evidence of endocrine disrupting activity. Ecotoxicology and Environmental Safety, 117, 7-19. https://doi.org/10.1016/j. ecoenv.2015.03.006.

Pimentel, M. F., Damasceno, É. P., Jimenez, P. C., Araújo, P. F. R., Bezerra, M. F., de Morais, P. C. V., et al. (2016). Endocrine disruption in Sphoeroides testudineus tissues and sediments highlights contamination in a northeastern Brazilian estuary. Environmental Monitoring and Assessment, 188(5), 298. https://doi.org/10.1007/s10661-016-5300-9.

Pinto, B., Garritano, S. L., Cristofani, R., Ortaggi, G., Giuliano, A., Amodio-Cocchieri, R., et al. (2008). Monitoring of polychlorinated biphenyl contamination and estrogenic activity in water, commercial feed and farmed seafood. Environmental Monitoring and Assessment, 144(1-3), 445453. https://doi.org/10.1007/s10661-007-0007-6.

Pleil, J. D., Vette, A. F., Johnson, B. A., \& Rappaport, S. M. (2004). Air levels of carcinogenic polycyclic aromatic hydrocarbons after the World Trade Center disaster. Proceedings of the National Academy of Sciences of the United States of America, 101(32), 11685-11688. https://doi.org/10.1073 /pnas.0404499101.

Praveena, S. M., Hamin, N., Razak, S. Q. N. A., \& Aris, A. Z. (2016). Analysis of steroid estrogens in river sediment by high performance liquid chromatography-electrospray ionization-mass spectrometry. Iranian Journal of Science and Technology, Transactions A: Science. https://doi. org/10.1007/s40995-016-0109-5.

Rasier, G., Toppari, J., Parent, A.-S., \& Bourguignon, J.-P. (2006). Female sexual maturation and reproduction after prepubertal exposure to estrogens and endocrine disrupting chemicals: a review of rodent and human data. Molecular and Cellular Endocrinology, 254-255, 187-201. https://doi.org/10.1016/j. mce.2006.04.002.

Reungoat, J., Escher, B. I., Macova, M., Argaud, F. X., Gernjak, W., \& Keller, J. (2012). Ozonation and biological activated carbon filtration of wastewater treatment plant effluents. Water Research, 46(3), 863-872. https://doi.org/10.1016/j. watres.2011.11.064.

Rigdon, R. H., \& Rennels, E. G. (1964). Effect of feeding benzpyrene on reproduction in the rat. Experientia, 20(4), 224-226 http://www.ncbi.nlm.nih.gov/pubmed/5892565.

Rocha, M. J., Cruzeiro, C., Reis, M., Pardal, M. Â., \& Rocha, E. (2015). Toxicological relevance of endocrine disruptors in the Tagus River estuary (Lisbon, Portugal). Environmental Monitoring and Assessment, 187(8), 483. https://doi. org/10.1007/s10661-015-4679-z.

Rosa, R. M. R. (2008). Contribuição para o estudo de compostos desreguladores endócrinos(EC) em ETAR.

Sadikovic, B., \& Rodenhiser, D. I. (2006). Benzopyrene exposure disrupts DNA methylation and growth dynamics in breast cancer cells. Toxicology and Applied Pharmacology, 216(3), 458-468. https://doi.org/10.1016/J.TAAP.2006.06.012.

Salste, L., Leskinen, P., Virta, M., \& Kronberg, L. (2007). Determination of estrogens and estrogenic activity in wastewater effluent by chemical analysis and the bioluminescent yeast assay. The Science of the Total Environment, 378(3), 343-351. https://doi.org/10.1016/j.scitotenv.2007.02.030.

Santodonato, J. (1997). Review of the estrogenic and antiestrogenic activity of polycyclic aromatic hydrocarbons: Relationship to carcinogenicity. Chemosphere, 34(4), 835848 http://www.ncbi.nlm.nih.gov/pubmed/9569946.

Schecter, A., Lorber, M., Guo, Y., Wu, Q., Yun, S. H., Kannan, K., et al. (2013). Phthalate concentrations and dietary exposure from food purchased in New York state. Environmental Health Perspectives, 121(4), 473-494. https://doi. org/10.1289/ehp.1206367.

Schilirò, T., Pignata, C., Rovere, R., Fea, E., \& Gilli, G. (2009). The endocrine disrupting activity of surface waters and of wastewater treatment plant effluents in relation to chlorination. Chemosphere, 75(3), 335-340. https://doi.org/10.1016 j.chemosphere.2008.12.028.

Schug, T. T., Janesick, A., Blumberg, B., \& Heindel, J. J. (2011). Endocrine disrupting chemicals and disease susceptibility. Journal of Steroid Biochemistry and Molecular Biology, 127(3-5), 204-215. https://doi.org/10.1016/j. jsbmb.2011.08.007.

Schwaiger, J., Spieser, O. H., Bauer, C., Ferling, H., Mallow, U., Kalbfus, W., \& Negele, R. D. (2000). Chronic toxicity of nonylphenol and ethinylestradiol: Haematological and 
histopathological effects in juvenile common carp (Cyprinus carpio). Aquatic Toxicology (Amsterdam, Netherlands), 51(1), 69-78 http://www.ncbi.nlm.nih.gov/pubmed/10998500.

Selvaraj, K. K., Sundaramoorthy, G., Ravichandran, P. K., Girijan, G. K., Sampath, S., \& Ramaswamy, B. R. (2015). Phthalate esters in water and sediments of the Kaveri River, India: Environmental levels and ecotoxicological evaluations. Environmental Geochemistry and Health, 37(1), 83-96. https://doi.org/10.1007/s10653-014-9632-5.

Servos, M. R. (1999). Review of the aquatic toxicity, estrogenic responses and bioaccumulation of alkylphenols and alkylphenol polyethoxylates. Water Quality Research Journal of Canada, 34(1), 123-177 http://www.ncbi.nlm. nih.gov/pubmed/1881.

Shahidehnia, M. (2016). Epigenetic effects of endocrine disrupting chemicals. Journal of Environmental \& Analytical Toxicology, 6(4). https://doi.org/10.4172/21610525.1000381 .

Shaw, I., \& McCully, S. (2002). A review of the potential impact of dietary endocrine disrupters on the consumer. International Journal of Food Science and Technology, 37(5), 471-476. https://doi.org/10.1046/j.13652621.2002.00595.x.

Shimada, K., Mitamura, K., \& Higashi, T. (2001). Gas chromatography and high-performance liquid chromatography of natural steroids. Journal of Chromatography A, 935(1-2), 141-172 http://www.ncbi.nlm.nih.gov/pubmed/11762773.

Shore, L. S., Gurevitz, M., \& Shemesh, M. (1993). Estrogen as an environmental pollutant. Bulletin of Environmental Contamination and Toxicology, 51(3), 361-366. https://doi. org/10.1007/s00128-016-1873-9.

Sievers, C. K., Shanle, E. K., Bradfield, C. A., \& Xu, W. (2013). Differential action of monohydroxylated polycyclic aromatic hydrocarbons with estrogen receptors $\alpha$ and $\beta$. Toxicological Sciences, 132(2), 359-367. https://doi.org/10.1093 /toxsci/kfs287.

Simpson, M. G., Parry, M., Kleinkauf, A., Swarbreck, D., Walker, P., \& Leah, R. T. (2000). Pathology of the liver, kidney and gonad of flounder (Platichthys flesus) from a UK estuary impacted by endocrine disrupting chemicals. Marine Environmental Research, 50(1-5), 283-287 http://www. ncbi.nlm.nih.gov/pubmed/11460705.

Snyder, S. A., Westerhoff, P., Yoon, Y., \& Sedlak, D. L. (2003). Pharmaceuticals, personal care products, and endocrine disruptors in water: implications for the water industry. Environmental Engineering Science, 20(5), 449-469. https://doi.org/10.1089/109287503768335931.

Soares, A., Guieysse, B., Jefferson, B., Cartmell, E., \& Lester, J. N. (2008). Nonylphenol in the environment: a critical review on occurrence, fate, toxicity and treatment in wastewaters. Environment International, 34(7), 1033-1049. https://doi. org/10.1016/j.envint.2008.01.004.

Song, W. T., \& Wang, Z. J. (2016). Occurrence and biological effects of endocrine disrupting chemicals in the Yellow River (Zhengzhou section). Bulletin of Environmental Contamination and Toxicology, 97(6), 763-769. https://doi. org/10.1007/s00128-016-1930-4.

Srivastava, S. K. (2015). SPR based Fiber optic sensor for the detection of vitellogenin: an endocrine disruption biomarker in aquatic environments. Biosensors Journal, 4(1). https://doi.org/10.4172/2090-4967.1000114.
Staples, C. A., Dorn, P. B., Klecka, G. M., O’Block, S. T., \& Harris, L. R. (1998). A review of the environmental fate, effects, and exposures of bisphenol A. Chemosphere, 36(10), 2149-2173 http://www.ncbi.nlm.nih.gov/pubmed/9566294.

Stringer, R., Labunska, I., Santillo, D., Johnston, P., Siddorn, J., \& Stephenson, A. (2000). Concentrations of phthalate esters and identification of other additives in PVC children's toys. Environmental Science and Pollution Research International, 7(1), 27-36. https://doi.org/10.1065 /espr199910.007.

Sun, L., Zha, J., \& Wang, Z. (2009). Interactions between estrogenic chemicals in binary mixtures investigated using vitellogenin induction and factorial analysis. Chemosphere, 75(3), 410-415. https://doi.org/10.1016/j. chemosphere.2008.11.083.

Sun, J., Huang, J., Zhang, A., Liu, W., \& Cheng, W. (2013). Occurrence of phthalate esters in sediments in Qiantang River, China and inference with urbanization and river flow regime. Journal of Hazardous Materials, 248-249(1), 142149. https://doi.org/10.1016/j.jhazmat.2012.12.057.

Sweeney, M. F., Hasan, N., Soto, A. M., \& Sonnenschein, C. (2015). Environmental endocrine disruptors: effects on the human male reproductive system. Reviews in Endocrine \& Metabolic Disorders, 16(4), 341-357. https://doi. org/10.1007/s11154-016-9337-4.

Tammen, S. A., Friso, S., \& Choi, S.-W. (2013). Epigenetics: the link between nature and nurture. Molecular Aspects of Medicine, 34(4), 753-764. https://doi.org/10.1016/j. mam.2012.07.018.

Trudeau, V., \& Tyler, C. (2007). Endocrine disruption. General and Comparative Endocrinology, 153(1-3), 13-14. https://doi.org/10.1016/j.ygcen.2007.06.003.

Tsay, J. J., Tchou-Wong, K.-M., Greenberg, A. K., Pass, H., \& Rom, W. N. (2013). Aryl hydrocarbon receptor and lung cancer. Anticancer Research, 33(4), 1247-1256 http://www. ncbi.nlm.nih.gov/pubmed/23564762.

Upson, K., Sathyanarayana, S., De Roos, A. J., Thompson, M. L., Scholes, D., Dills, R., \& Holt, V. L. (2013). Phthalates and risk of endometriosis. Environmental Research, 126, 91-97. https://doi.org/10.1016/J.ENVRES.2013.07.003.

Urase, T., \& Kikuta, T. (2005). Separate estimation of adsorption and degradation of pharmaceutical substances and estrogens in the activated sludge process. Water Research, 39(7), 12891300. https://doi.org/10.1016/j.watres.2005.01.015.

USEPA. (2006). Aquatic Life Ambient Water Quality Criteria. https://www.epa.gov/wqc/national-recommended-waterquality-criteria-aquatic-life-criteria-table. Accessed 17 Apr 2016.

USEPA. (2010). Nonylphenol and nonylphenol ethoxylates action plan. https://www.epa.gov/assessing-and-managingchemicals-under-tsca/nonylphenol-np-and-nonylphenolethoxylates-npes

USEPA. (2011). What is Endocrine Disruption? https://www.epa. gov/endocrine-disruption/what-endocrine-disruption. Accessed 5 June 2017.

USEPA. (2012). Guidelines for ensuring and maximizing the quality, objectivity, utility, and integrity of information disseminated by the Environmental Protection Agency, 515(1), 1-61. papers3://publication/uuid/CFDFE430-B1C3-429CB0F0-7F52DBCDB0F4. 
Vagi, S. J., Azziz-Baumgartner, E., Sjödin, A., Calafat, A. M., Dumesic, D., Gonzalez, L., et al. (2014). Exploring the potential association between brominated diphenyl ethers, polychlorinated biphenyls, organochlorine pesticides, perfluorinated compounds, phthalates, and bisphenol A in polycystic ovary syndrome: A case-control study. BMC Endocrine Disorders, 14, 86. https://doi.org/10.1186/14726823-14-86.

Vajda, A. M., Barber, L. B., Gray, J. L., Lopez, E. M., Woodling, J. D., \& Norris, D. O. (2008). Reproductive disruption in fish downstream from an estrogenic wastewater effluent. Environmental Science \& Technology, 42(9), 3407-3414 http://www.ncbi.nlm.nih.gov/pubmed/18522126.

Van de Wiele, T., Vanhaecke, L., Boeckaert, C., Peru, K., Headley, J., Verstraete, W., \& Siciliano, S. (2005). Human colon microbiota transform polycyclic aromatic hydrocarbons to estrogenic metabolites. Environmental Health Perspectives, $113(1), 6-10$ http://www.ncbi.nlm.nih. gov/pubmed/15626640.

Vandenberg, L. N. (2014a). Non-monotonic dose responses in studies of endocrine disrupting chemicals: Bisphenol a as a case study. Dose-Response, 12(2), 259-276. https://doi. org/10.2203/dose-response.13-020.Vandenberg.

Vandenberg, L. N. (2014b). Low-dose effects of hormones and endocrine disruptors. Vitamins \& Hormones, 94, 129-165. https://doi.org/10.1016/B978-0-12-800095-3.00005-5.

Vandenberg, L. N., Colborn, T., Hayes, T. B., Heindel, J. J., Jacobs, D. R., Lee, D.-H., et al. (2012). Hormones and endocrine-disrupting chemicals: low-dose effects and nonmonotonic dose responses. Endocrine Reviews, 33(3), 378-455. https://doi.org/10.1210/er.2011-1050.

Varayoud, J., Monje, L., Bernhardt, T., Muñoz-de-Toro, M., Luque, E. H., \& Ramos, J. G. (2008). Endosulfan modulates estrogen-dependent genes like a non-uterotrophic dose of 17ß-estradiol. Reproductive Toxicology, 26(2), 138-145. https://doi.org/10.1016/J.REPROTOX.2008.08.004.

Vega-López, A., Ramón-Gallegos, E., Galar-Martínez, M., Jiménez-Orozco, F. A., García-Latorre, E., \& DomínguezLópez, M. L. (2007). Estrogenic, anti-estrogenic and cytotoxic effects elicited by water from the type localities of the endangered goodeid fish Girardinichthys viviparus. Comparative Biochemistry and Physiology Toxicology \& Pharmacology: CBP, 145(3), 394-403. https://doi. org/10.1016/j.cbpc.2007.01.008.

Verderame, M., Limatola, E., \& Scudiero, R. (2016). Estrogenic contamination by manure fertilizer in organic farming: a case study with the lizard Podarcis sicula. Ecotoxicology (London, England), 25(1), 105-114. https://doi.org/10.1007/s10646015-1571-0.

Vogel, S. A. (2009). The politics of plastics: the making and unmaking of bisphenol a "safety". American Journal of Public Health, 99(Suppl 3), S559-S566. https://doi. org/10.2105/AJPH.2008.159228.

vom Saal, F. S., \& Welshons, W. V. (2006). Large effects from small exposures. II. The importance of positive controls in low-dose research on bisphenol A. Environmental Research, 100(1), 50-76. https://doi.org/10.1016/J. ENVRES.2005.09.001.

Wang, L., Ying, G.-G., Chen, F., Zhang, L.-J., Zhao, J.-L., Lai, H.J., et al. (2012). Monitoring of selected estrogenic compounds and estrogenic activity in surface water and sediment of the Yellow River in China using combined chemical and biological tools. Environmental Pollution (Barking, Essex: 1987), 165, 241-249. https://doi.org/10.1016/j. envpol.2011.10.005.

Wang, B., Dong, F., Chen, S., Chen, M., Bai, Y., Tan, J., et al. (2016). Phenolic endocrine disrupting chemicals in an urban receiving river (Panlong river) of Yunnan-Guizhou plateau: occurrence, bioaccumulation and sources. Ecotoxicology and Environmental Safety, 128, 133-142. https://doi.org/10.1016 j.ecoenv.2016.02.018.

Wenzel, K.-D., Hubert, A., Manz, M., Weissflog, L., Engewald, W., \& Schüürmann, G. (1998). Accelerated solvent extraction of semivolatile organic compounds from biomonitoring samples of pine needles and mosses. Analytical Chemistry, 70(22), 4827-4835. https://doi.org/10.1021/ac9806299.

Whirledge, S., Senbanjo, L. T., \& Cidlowski, J. A. (2015). Genistein disrupts glucocorticoid receptor signaling in human uterine endometrial Ishikawa cells. Environmental Health Perspectives, 123(1), 80-87. https://doi.org/10.1289 /ehp.1408437.

White, R., Jobling, S., Hoare, S. A., Sumpter, J. P., \& Parker, M. G. (1994). Environmentally persistent alkylphenolic compounds are estrogenic. Endocrinology, 135(1), 175-182. https://doi.org/10.1210/endo.135.1.8013351.

Wu, J.-Y., Xu, Q.-J., Gao, G., \& Shen, J.-H. (2006). Evaluating genotoxicity associated with microcystin-LR and its risk to source water safety in Meiliang Bay, Taihu Lake. Environmental Toxicology, 21(3), 250-255. https://doi. org/10.1002/tox.20178.

Wu, M., Pan, C., Yang, M., Xu, B., Lei, X., Ma, J., et al. (2016). Chemical analysis of fish bile extracts for monitoring endocrine disrupting chemical exposure in water: Bisphenol A, alkylphenols, and norethindrone. Environmental Toxicology and Chemistry, 35(1), 182-190. https://doi.org/10.1002 /etc. 3176 .

Yamamoto, H., Liljestrand, H. M., Shimizu, Y., \& Morita, M. (2003). Effects of physical-chemical characteristics on the sorption of selected endocrine disruptors by dissolved organic matter surrogates. Environmental Science \& Technology, 37(12), 2646-2657 http://www.ncbi.nlm.nih. gov/pubmed/12854701.

Yang, J., Zhang, Y., Wang, Y., \& Cui, S. (2007). Toxic effects of zearalenone and $\alpha$-zearalenol on the regulation of steroidogenesis and testosterone production in mouse Leydig cells. Toxicology In Vitro, 21(4), 558-565. https://doi.org/10.1016 /J.TIV.2006.10.013.

Yang, O., Kim, H. L., Weon, J.-I., \& Seo, Y. R. (2015). Endocrinedisrupting chemicals: Review of toxicological mechanisms using molecular pathway analysis. Journal of Cancer Prevention, 20(1), 12-24. https://doi.org/10.15430 /JCP.2015.20.1.12.

Yin, G.-G., Kookana, R. S., \& Ru, Y.-J. (2002). Occurrence and fate of hormone steroids in the environment. Environment International, 28(6), 545-551 http://www.ncbi.nlm.nih. gov/pubmed/12503920.

Ying, G.-G. (2012). Endocrine disrupting chemicals. What? Where? In Analysis of endocrine disrupting compounds in food (pp. 3-17). Oxford: Wiley-Blackwell. https://doi. org/10.1002/9781118346747.ch1.

Ying, G.-G., Williams, B., \& Kookana, R. (2002). Environmental fate of alkylphenols and alkylphenol ethoxylates-a review. 
Environment International, 28(3), 215-226 http://www.ncbi. nlm.nih.gov/pubmed/12222618.

Yu, L., Ham, K., Gao, X., Castro, L., Yan, Y., Kissling, G. E., et al. (2016). Epigenetic regulation of transcription factor promoter regions by low-dose genistein through mitogen-activated protein kinase and mitogen-and-stress activated kinase 1 nongenomic signaling. Cell communication and signaling: CCS, 14(1), 18. https://doi.org/10.1186/s12964-016-0141-2.

Zama, A. M., \& Uzumcu, M. (2010). Epigenetic effects of endocrine-disrupting chemicals on female reproduction: an ovarian perspective. Frontiers in Neuroendocrinology, 31(4), 420-439. https://doi.org/10.1016/j.yfrne.2010.06.003.

Zhang, J., Chang, L., Jin, H., Xia, Y., Wang, L., He, W., et al. (2016). Benzopyrene promotes lung cancer A549 cell migration and invasion through up-regulating cytokine IL8 and chemokines CCL2 and CCL3 expression. Experimental Biology and Medicine, 241(14), 1516-1523. https://doi. org/10.1177/1535370216644530.

Zhao, J.-L., Ying, G.-G., Yang, B., Liu, S., Zhou, L.-J., Chen, Z.F., \& Lai, H.-J. (2011). Screening of multiple hormonal activities in surface water and sediment from the Pearl River system, South China, using effect-directed in vitro bioassays. Environmental Toxicology and Chemistry, 30(10), 2208-2215. https://doi.org/10.1002/etc.625.

Zhou, R., Cheng, W., Feng, Y., Wei, H., Liang, F., \& Wang, Y. (2017). Interactions between three typical endocrinedisrupting chemicals (EDCs) in binary mixtures exposure on myocardial differentiation of mouse embryonic stem cell. Chemosphere, 178, 378-383. https://doi.org/10.1016/j. chemosphere.2017.03.040. 